\title{
Spatio-temporal distribution of soft-bottom epibenthic fauna on the Cilician shelf (Turkey), Mediterranean Sea
}

\author{
Erhan Mutlu ${ }^{1} \&$ Mehmet Betil Ergev ${ }^{2}$ \\ 1. Institute of Marine Sciences and Technology, Dokuz Eylul University, Inciralti, Izmir, Turkey; erhan.mutlu@deu.edu.tr \\ 2. Derinsu Underwater Engineering \& Consulting Company, Nilgun Sk. 5/1, Kavaklıdere, 06680 Ankara, Turkey
}

Received 14-IX-2007. Corrected 16-V-2008. Accepted 18-VIII-2008.

\begin{abstract}
Spatio-temporal distribution of epifauna collected with a sledge was studied on the Cilician shelf of the Mediterranean Sea. There were two different communities: the shallow community was restricted to water at 5 and $10 \mathrm{~m}$ deep with sandy bottom inhabited abundantly by Conomurex persicus, Arnoglossus laterna and Murex trunculus. Conomurex persicus, an introduced tropical species predominated the shallow zone and distinguished it from the deep zone. The deep community $(25-150 \mathrm{~m})$ lacked shallow water species and was dominated by Arnoglossus laterna, Goneplax rhomboides and Parapenaeus longirostris. Seasonality was not a major factor in the epibenthic community structure of the entire shelf, but it is in the shallow waters. Bottom depth was main factor for structuring the community on the shelf. Sediment size and organic content is also a controlling factor for the distribution of the epibenthic fauna. Rev. Biol. Trop. 56 (4): 1919-1946. Epub 2008 December 12 .
\end{abstract}

Key words: Epifauna, distribution, Cilician shelf, Eastern Mediterranean Sea.

Mediterranean marine communities have a greater diversity of small, short-lived individuals when compared to the Atlantic. Benthic species richness in the Mediterranean is estimated as approximately 7250 with approximately 6 000 animals (Fredj et al. 1992). Recent number of species of some zoobenthic groups in the whole Mediterranean Sea was as follows: 1 000 Polychaeta species, 2000 Mollusca, 154 Echinodermata, 1935 Arthropoda (Amphipoda 451, Decapoda 340, Isopoda 165, Anisopoda 43, Cumacea 91 and miscellaneous 845 species), 33 Sipuncula, 500 Bryozoa and 622 Porifera (UNEP/MAP 2004). Until December 2005, alien species in the Mediterranean was estimated to be 745 species (Zenetos et al. 2005). Species richness in the Mediterranean has been changing with the increasing number of introduced lessepsian species (Bakir et al 2006, Ozcan .et al 2006, Yokes et al. 2007, Galil 2005, Yokes and Galil 2006, Horton et al. 2004, Galil 2004, Cinar and Altug 2007).
The diversity in the studied assemblage of the Eastern Mediterranean was relatively poor when compared with those from the Western sites (Cardel et al. 1999, Sarda et al. 1999, Gusso et al. 2001). According to the estimations of Koukouras et al. (2001) updated out of a total of about 6000 benthic invertebrate species in the Mediterranean, about 67\% (4 030) are found in the western Mediterranean, $38 \%$ (2 262) in the Adriatic Sea, 35\% (2 119) in the Central Mediterranean, 44\% (2 637) in the Aegean, and 28\% (1 658) in the Levantine Sea. This trend in number of species demonstrates a west-east zoogeocline: a large number of geographic, climatic and trophic variables are highly correlated with this pattern which has been found to be similar for many taxonomic groups. Most benthic studies in the eastern Mediterranean Sea have been conducted in the Aegean Sea end (Bellan-Santini 1985, Farina et al. 1997a, Tselepides et al. 2000, Smith et al. 2000, Kallianiotis et al. 2000). 
To date, there are a few studies on the epibenthic community from the Turkish coast of the Mediterranean Sea, and no seasonal studies on spatio-temporal distribution on epifauna. It is necessary to conduct such a study because it is not possible to use estimates from other areas because the number of species varies among locations around the Eastern Mediterranean Sea. Ergen and Cinar (1997) reported 129 Polychaeta (Annelida) species from Antalya Bay. Kocatas et al. (2004) recorded 81 crustacean species as a Cystoseria facies (1 Cumacea, 2 Tanaidacea, 23 Isopoda, 36 Amphipoda and 19 Decapoda) from the Turkish Aegean coasts whereas Kirim et al. (2005) found 85 species as Padina facies and Ates et al. (2005) recorded a total of 40 decapod species.

Epifaunal studies by means of continuously dredging could change ecological characterization of the community. This may be the case for the macrobenthic community inhabiting the shallow sandy bottoms of the area considered in this study. Frequent small-scale disturbances, such as dredging operations, may thus be masked by large-scale environmental perturbations, such as storms, and prevailing hydrodynamic processes may be among the key factors determining the extent to which an area will be resilient to fishing disturbance (Morello et al. 2006). The community structure the continuously fished area was dominated by small, opportunistic, short-lived species while the community structure of the recently non-fished area was dominated by more fragile and lon-living sessile organisms in dredged and non-dredged fishing areas (Eleftheriou and Robertson 1992, Simboura et al. 1998, Smith et al. 2000, Sarda et al. 2000, Gusso et al. 2001, Chicharo et al. 2002, Kamenos et al. 2003).

State of the papers reviewed above shows that the Cilician shelf particularly large area of Levantine Sea has not been considered with regard of the soft-bottom megafauna. The present study was the first seasonal macrobenthic epifaunal community study in the Mediterranean coast of Turkey, even in Turkish waters, particularly during post period of Conomurex persicus' introduction (succession recently occurred in Argolikos Bay and Crete, Greece, Zenetos et al. 2002) and examines spatio-temporal distribution of the community in the investigated area, with regard to environmental characteristics.

\section{MATERIALS AND METHODS}

The study was conducted on a section of Levantine (Mediterranean Sea) continental shelf off Erdemli, Mersin Bay, Turkey (Fig. 1A). The Lamas River and a few brooks are the major source of terrestrial freshwater and organic input. Depth contours generally parallel the coast. There are no seagrass bed communities in the study area and only shallow rocky sites like the two harbors are covered by epilithic algae (Fig. 1B). Most dominant species of the shallow waters is Conomurex persicus which inhabited on the sandy bottom with depth of generally $1 \mathrm{~m}$ to $10 \mathrm{~m}$, extending down to $20 \mathrm{~m}$ (Mutlu and Ergev 2006).

Benthic samples collection: Samples of soft bottom epifauna were collected using the epibenthic sledge of Hessler and Sanders $(60 \mathrm{x}$ $15 \mathrm{~cm}$ mouth opening, $0.5 \times 0.5 \mathrm{~cm}$ mesh size: Holme and McIntyre, 1971) deployed by R/V Erdemli of Institute of Marine Sciences-Middle East Technical University (IMS-METU) in the study area (Fig. 1A). Sledges lasted about 15 min at 2 knots. Geographical coordinates were fixed from GPS to estimate distance trawled on the bottom.

Each sample was washed in a sieve $(0.5$ $\mathrm{mm}$ square mesh). On board, samples with total number of individuals higher than about 500 inds (i.e. a gastropod Conomurex persicus) were sub-sampled, with 3-5 jars each containing 70-90 randomly taken specimens preserved, and the rest of these samples were only counted.

Macrofaunal assemblages at the shallow waters seem to be shaped by the sediment properties which are indeed more heterogeneous than those at the deeper areas (Karakassis and Eleftheriou 1997). Therefore, two sampling temporal frequencies were conducted with 

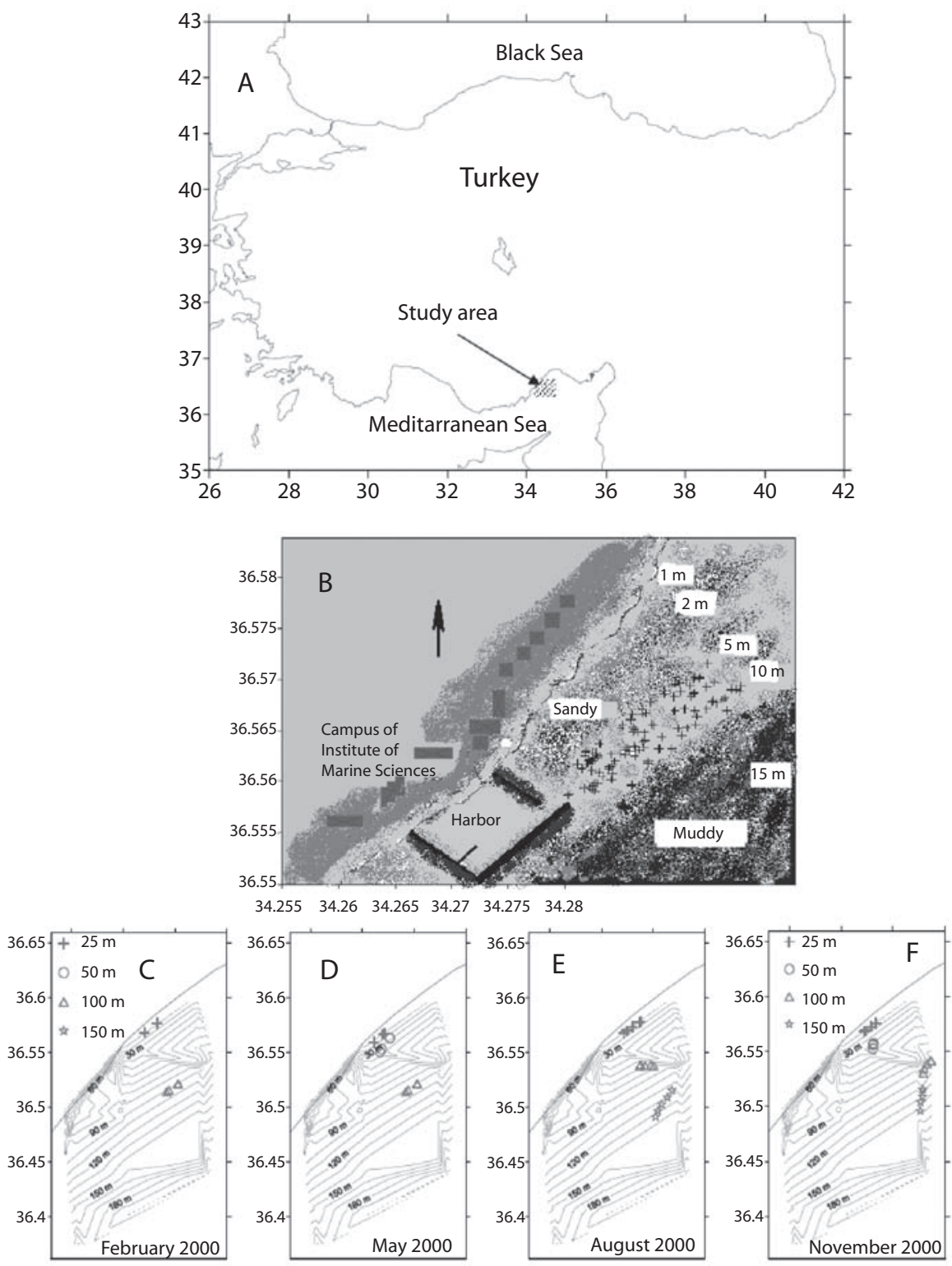

Fig. 1.A. The study area; (B.) monthly sampling line stations (+) at 5 and $10 \mathrm{~m}$ depth contours at the shallow waters between February 2000 and April 2002; and (C-F) seasonal sampling line stations of the deep waters in February (C), May (D), August (E) and November (F) during year 2000.

respect to the zones: shallow water and deep water of the Cilician shelf.

\section{Sampling frequency at shallow waters:} Shallow water has been restricted to depth gradient up to $10 \mathrm{~m}$. Bottom of the shallow zone was composed of pure sand sediment ( $>99 \%)$ and physically disturbed by currents, waves, climate and anthropogenic riverine sources. In the Mediterranean Sea, the zone has been classified as a part of "fine, well-sorted sand" (SFBC, Peres 1982a). Makra and Nicolaidou 
(2000) found two communities of the infralittoral zone, that of Muddy Sand in Sheltered Areas (SVMC) and that of SFBC under disturbance and/or eutrophication in the Eastern Mediterranean. The zone was temporally very dynamic and well-diversified in epifaunal species and abundance, due mainly and recently to an indo-pacific dominant species, Conomurex persicus which showed interannual and monthly variation in population (Mutlu and Ergev 2006). Considering defined temporal variability samples of epifaunal individuals were collected monthly along the 5 and $10 \mathrm{~m}$ depth contours off Erdemli, Mersin (Fig. 1B) from June 2000 to November 2001, and then seasonally between February and April 2002 and between February and May 2000. In few cases, sampling depths were overlapped (Fig. 1B)

2. Sampling frequency at deep water: The community inhabiting mixed sediments deeper than $10 \mathrm{~m}$ was ascribable to the MuddyDetritic community (DE, according to Peres 1967) composed mainly of mud, sand and detritus dwelling species. Deep water was highly variable only seasonally in hydrographical characteristics and more homogenous in the epifaunal community than the shallow waters. Therefore, the sampling duration was kept for one year during 2000 and the quarterly sledges were sampled: at 25 and $100 \mathrm{~m}$ in February; at 25,50 and $100 \mathrm{~m}$ in May; at 25, 110 and $155 \mathrm{~m}$ in August; and at 25, 50, 100 and 150 $\mathrm{m}$ in November (Fig. 1C). Additionally, the samples were taken at 5 and $10 \mathrm{~m}$ to observe variability of epifaunal community transecting to deep waters in February, May, August and November during year 2000 (Fig. 1B).

Environmental data collection: Temperature, salinity and density were measured using a SeaBird Oceanographic probe (SBE Seacat 19 plus CTD). Bottom sediment was collected at each station with a Van Veen grab and was packed in a nylon bag and frozen for geological analyses (grain size, total carbonate and organic carbon contents of the sediment).
Laboratorial works: Epifaunal species and any demersal fish caught in the dredge were identified; counted and weighed (however, total wet weight of polychaetes was measured for each sample because most of the specimens were fragmented). Abundance and biomass was standardized in number of individuals and wet weight $\mathrm{m}^{-2}$ based on the sampling distance. Analyses were completed using standard processes for: grain size using the wet/dry sieving and pipette methods (Folk 1974); total carbonate percentage (Muller 1967), and total organic carbon (Gaudette et al. 1974). Environmental parameters sampled at each station were surface/near bottom water temperature, salinity, density, and grain size (gravel, sand, silt and clay), total carbonate, organic carbon and inorganic carbon of the sediment.

\section{Statistical treatment}

1. Sub-sampling: Efficiency of the subsampling method from just big net tows was statistically tested involving abundances into dispersion index (Anonymous 1991). The calculated indices showed that the sub-sampling was significantly efficient at $\mathrm{p}<0.05$.

2. Univariate and multivariate statistics: Non-parametric Spearman rank correlation coefficients were calculated for assessing the degree to which numbers of individuals of the main epifaunal taxa were correlated together (Sokal and Rohlf 1973). The autocorrelation (Box and Jenkins 1976) function was used to identify an appropriate time series model for temporal variation in abundance of each taxa for the shallow waters.

Diversity indices (Margalef's richness, Pielou's evenness and Shannon-Weiner index) were calculated at each sampling site (Margalef 1985, Pielou 1966, Shannon and Weaver 1968). Principal Component Analyses (PCA) was applied to the environmental data subjected separately under two different matrices (hydrographical and sedimentary structures) to explain major variation occurred in the 
shelf the throughout the year 2000. Abundance data $(\mathrm{X})$ were transformed using $\log _{10}(\mathrm{X}+1)$ chosen a result of application of Taylor's Power Law (Taylor 1961). The transformation was necessary to weight the contributions of common and rare species in the multivariate representations (Field et al. 1982). Epifaunal abundance among sites was tested using multivariate analyses (cluster, MDS and SIMPER, ANOSIM) described by Clarke and Green (1988) and Clarke and Warwick (1993). ANOSIM (Analysis of Similarities) was used to test for differences among groups of samples based on the (ranked) similarity matrix from the cluster. SIMPER examined the contribution of individual species to the similarity measure (Bray-Curtis Similarity index, Bray and Curtis 1957). CLUSTER performed hierarchical agglomerative clustering of species/sample data with group average linkage (Clarke and Warwick 2001). Ordination (nonmetric multidimensional scaling MDS) was used to evaluate the group separation derived from cluster analysis (Field et al. 1982). Environmental variables were regressed by superimposing on the epifaunal ordinations (MDS) so as to visually find subset of the variables whose MDS ordination best matches the epifaunal ordination. Additionally, canonical correlation analysis (Anderson and Robinson 2003, Anderson and Willis 2003), extremely informative, was applied to a dissimilarity matrix (Bray-curtis) based on $\log _{10}(\mathrm{X}+1)$ transformed abundance matrix of the epifaunal assemblages to test intra (seasonal) or interannual and contour depthwise $(5 \mathrm{~m}, 10$ $\mathrm{m}$, and 25-150 $\mathrm{m}$ ) differences. The resulting scores were then analyzed using generalized discriminant analysis (CAP), giving tests based on the canonical correlations. All these statistical analyses were undertaken using the package PRIMER, (ver. 5.3.1, Clark and Warwick 2001), STATISTICA (98 Edition) and FATHOM (Jones 2002).

\section{RESULTS}

\section{Study site and environmental parameters}

Physical properties (temperature, salinity and density) of the shallow waters are variable, depending on atmospheric forcing. In the shallow zones, water temperature was generally isothermal from the surface to bottom and varied between 16 and $\sim 30{ }^{\circ} \mathrm{C}$. The temperature was below $20^{\circ} \mathrm{C}$ during November-May and then rose abruptly to $\sim 30{ }^{\circ} \mathrm{C}$ in August. There could occasionally be difference in temperatures at surface, $5 \mathrm{~m}$ and $10 \mathrm{~m}$ depths: the temperature was $\sim 4{ }^{\circ} \mathrm{C}$ warmer at the surface than at $10 \mathrm{~m}$ in July/August in 2002 and 2 degrees warmer in May 2000. Typically salinity of the area was about 39 psu, which was observed from July 2000 to December 2001. Hydrographical features of the shallow zone were further detailed in a study (Mutlu and Ergev 2006). In the deep zone, temperature of the water column in year 2000 varied between 15.5 (February) and 29.3 ${ }^{\circ} \mathrm{C}$ (August), salinity between 38.08 (May) and 39.95 (August) and density 25.27 (August) and 28.84 sigma-theta (November, Table 1). PC1 explained half (52\%) of total variation for the physical parameters on the shelf. Sea surface (SST) and Near-bottom water temperature (NBT) contrasted with water densities (SSD and NBD) were major factors in the linear combinations of variables making up PC1 for seasonal variations of the study area. On PC2, the same variables explained $20 \%$ of seasonal changes in physical measurements. So physical measurements were variable in two-way: temporal (seasonal) and spatial (depths) dimensions in the study area.

Superficial sediment composition did not show significant differences over time. On the band between 80 and $100 \mathrm{~m}$, there were some small-scale aggregations $(>12 \%)$ of the fraction gravel. Overall, gravel concentration did not exceed $20 \%$ while sand in the surface 
TABLE 1

Temporal variation in hydrographical measurements between shallow and deep waters on the Cilician shelf in year 2000

\begin{tabular}{|c|c|c|c|c|c|c|}
\hline \multirow[t]{2}{*}{ Months } & \multicolumn{2}{|c|}{ Temperature $\left({ }^{\circ} \mathrm{C}\right)$} & \multicolumn{2}{|c|}{ Salinity (psu) } & \multicolumn{2}{|c|}{ Density $\left(\sigma_{\theta}\right)$} \\
\hline & Shallow & Deep & Shallow & Deep & Shallow & Deep \\
\hline \multirow[t]{2}{*}{ February } & 15.5 & 18.0 & 38.74 & 39.06 & 28.64 & 28.54 \\
\hline & 16 & 16.5 & 38.96 & 39.04 & 28.80 & 28.83 \\
\hline \multirow[t]{2}{*}{ May } & 21.3 & 20.5 & 38.35 & 38.85 & 26.99 & 27.58 \\
\hline & 19.2 & 17 & 38.08 & 38.95 & 27.99 & 27.94 \\
\hline \multirow[t]{2}{*}{ August } & 29.3 & 28.7 & 39.17 & 39.31 & 25.27 & 25.41 \\
\hline & 29 & 16 & 38.95 & 39.95 & 25.56 & 28.71 \\
\hline \multirow[t]{2}{*}{ November } & 21.8 & 22.7 & 39.21 & 39.35 & 27.42 & 27.31 \\
\hline & 23 & 16.5 & 38.86 & 39.28 & 27.42 & 28.84 \\
\hline
\end{tabular}

Numbers in regular font are for sea surface, in bold font for near bottom.

sediments varied between 30 and 100\% from deep to shallow waters, in contrast to the mud (silt + clay) distribution: Silt content varied between 0 and $75 \%$. The concentration of clay was found to be low in May and August while it was higher in February and November. Clay predominated the sediment composition in depths greater than $100 \mathrm{~m}$. Percentage distribution of the total carbonate in the bottom sediments ranged from 16 to $55 \%$. Overall, total organic carbon (TOC) increased from 0.1 to $0.40 \%$ with increased bottom depth. On the shelf sedimentary structure and texture did not show seasonal and local linearization with variables as results of PCA but depthwise variation occurred in year 2000. PC1 explained 54\% of total variation even thought the structural ordination by PCA reached a cumulative variation of $92 \%$ by PC4, which resulted in that the texture became statistically homogeneous among the seasons. Mud, silt and sand were found to be significant variables associated with variations on PC1. On PC2, 18\% of total explained variation was due mainly to variation in total carbon and gravel content of the sediment. The stations were aggregated mainly depending on bottom depths on PCA ordination. Sand and finer grains were regularly variable in depth whereas carbon contents and gravel contents were locally variable due to occurrence of a carbonate zone composed of shell fragments between depths of 50 and $100 \mathrm{~m}$ in the study area (Ergin 1996, Ediger et al. 1997).

\section{Epifauna}

The epifauna was composed of 46 Scaphopoda and mollusca species, 36 Fish, 33 Polychaeta, 29 Crustacea, 6 Echinodermata, 2 Cnidaria (Anthozoa), 3 Sipuncula, 1 Nemertini, 2 Ascidiacea and 1 Pycnogonida. Of a total of 159 species, 59 species were found at the $5 \mathrm{~m}$ depth contour, 42 at $10 \mathrm{~m}, 76$ species at shallow waters, and 99 at deep waters (Table 2). Mean abundance and biomass were 9.2 ind $\mathrm{m}^{-2}$ and $3.1 \mathrm{~g} \mathrm{~m}^{-2}$ for the study area. Annual total abundance varied between 0.17 and 7.0 ind $\mathrm{m}^{-2}$ on the shelf whilst biomasses ranged from 0.44 $\mathrm{g} \mathrm{m}^{-2}$ to $1.18 \mathrm{~g} \mathrm{~m}^{-2}$. Epifaunal abundance was less in shallow waters than that in deeper areas. The highest abundance at $5 \mathrm{~m}$ depth contour was $\sim 2.5$ ind $\mathrm{m}^{-2}$ whereas it was 4.25 ind $\mathrm{m}^{-2}$ at $10 \mathrm{~m}$. Species diversity generally increased from winter to autumn, with two peaks in spring and autumn. Diversity also generally increased from shallow to deep waters with the highest value at $100 \mathrm{~m}$.

\section{Shallow water}

Species richness: A total of 76 species from 4 phyla was found throughout the year in the shallow waters (Table 2). Monthly total 
TABLE 2

Occurrence of the epifaunal species found at shallow waters $(5 \mathrm{~m}$, and $10 \mathrm{~m})$ and deep waters $(\leq 50 \mathrm{~m}$, and $>50 \mathrm{~m})$

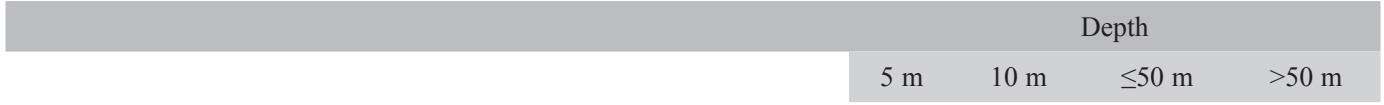

\section{Fish/Species}

Apogon nigripinis Cuvier, 1828

Arnoglossus laterna Walbaum, 1792

Arnoglossus sp.

Balistes capriscus Gronow, 1854

Bothus podas Delaroche, 1809

Buglossidium luteum Risso, 1810

Callionymus filamentosus Valenciennes, 1837

Callionymus sp.

Cynoglossus sinusarabici Chabanaud, 1931

Dactylopterus volitans Linnaeus, 1758

Gobius niger jozo Linnaeus, 1758

Gobius sp.

Lesueurigobius cf suerii

Lesueurigobius suerii Risso, 1810

Mullus barbatus Linnaeus, 1758

Mullus surmuletus Linnaeus, 1758

Muraenesox cinereus Forsskål, 1775

Neogobius sp.

Nemichthyidae sp.

Oxyurichthys petersi Klunzinger, 1871

Pagellus acarne Risso, 1827

Pagellus sp.

Raja clavata Linnaeus, 1758

Saurida undosquamis Richardson, 1848

Scorpaenodes arenai Torchio 1962

Serranus hepatus Linnaeus, 1758

Siganus luridus Rüppell, 1829

Solea sp.

Solea cuneata Moreau, 1881

Pegusa lascaris Risso, 1810

Stephanolepis diaspros Fraser-Brunner, 1940

Symphurus sp.

Synodontidae sp.

Trachinus draco Linnaeus, 1758 
TABLE 2 (Continued)

Occurrence of the epifaunal species found at shallow waters $(5 \mathrm{~m}$, and $10 \mathrm{~m})$ and deep waters $(\leq 50 \mathrm{~m}$, and $>50 \mathrm{~m})$

Chelidonichthys lucernus Linnaeus, 1758

\begin{tabular}{cccc} 
& \multicolumn{3}{c}{ Depth } \\
$5 \mathrm{~m}$ & $10 \mathrm{~m}$ & $\leq 50 \mathrm{~m}$ & $>50 \mathrm{~m}$ \\
+ & + & + & \\
& & +
\end{tabular}

Chelidonichthys lastoviza Bonnaterre, 1788

\section{Mollusca/Species}

Abra nitida O.F. Müller, 1776

Acanthocardia aculeata Linnaeus, 1758

Arca sp.

Astarte fusca Poli, 1795

Barbatia barbata Linné, 1758

Bittium latreilli Payraudeau, 1826

Bittium reticulatum da Costa, 1778

Chamelea gallina Linnaeus, 1758

Cardium tuberculatum Linnaeus, 1758

Ceretostoma erinaceum

Cerithium scabridum Philippi, 1848

Clumocardatum ciliatum

Conomurex persicus Swainson, 1821

Corbula gibba Olivi, 1792

Donax semistriatus Poli, 1795

Donax vittatus da Costa, 1778

Epitonium commutatum Monterosato

Gibbula richardi Payraudeau, 1826

Oenopota turricula Montagu, 1803

Mactra corallina Linnaeus, 1758

Murex trunculus

Buccinum undatum Linnaeus, 1758

Murex brandaris

Nassarius circumcinctus Adams A., 1852

Nassarius gibbosulus Linné, 1758

Nassarius mutabilis Linné, 1758

Natica sp. Scopoli, 1777

Naticarius punctatus Chemnitz in Karsten, 1789

Natica stercusmuscarum Gmelin, 1791

Nassarius granum Lamarck, 1822

Neverita josephinia Risso, 1826

Nucula nitidosa Winckworth, 1930 
TABLE 2 (Continued)

Occurrence of the epifaunal species found at shallow waters $(5 \mathrm{~m}$, and $10 \mathrm{~m})$ and deep waters $(\leq 50 \mathrm{~m}$, and $>50 \mathrm{~m})$

Ostrea edulis Linnaeus, 1758

\begin{tabular}{ccrr} 
& \multicolumn{2}{c}{ Depth } \\
$5 \mathrm{~m}$ & $10 \mathrm{~m}$ & $\leq 50 \mathrm{~m}$ & $>50 \mathrm{~m}$ \\
+ & + &
\end{tabular}

Paphia undulate Born, 1778

Phalium saburon Bruguière, 1792

Pinctada radiata Leach, 1814

Pteria hirundo Linnaeus, 1758

Rhinoclavis kochi Philippi, 1848

Fuscoscala turtonis Turton, 1819

Sepia officinalis L. 1758

Fusinus maroccensis Gmelin, 1791

Striarca lactea Linnaeus, 1758

Turbonilla acutissima Monterosato, 1884

Clausinella fasciata da Costa, 1778

\section{Scaphopoda/Species}

Dentalium tarentinum Lamarck, 1818

Dentaliidae sp.

\section{Crustacea/Species}

Alpheus glaber Olivi, 1792

Alpheus migrans Lewinsohn \& Holthuis, 1978

Alpheus rapacida De Man, 1908

Ampelisca sp.

Anapagurus hyndmanni Bell, 1845

Apseudes latreillii Milne-Edwards, 1828

Balanus sp.

Charybdis helleri A. Milne-Edwards, 1867

Corophium affine Bruzelius, 1859

Crangon crangon Linnaeus, 1758

Crangonidae sp.

Diogenes pugilator Roux, 1829

Ebalia cranchii Leach, 1817

Eurydice pulchra Leach, 1815

Eurynome aspera Pennant, 1777

Gnathia maxillaries Montagu, 1804

Goneplax rhomboids Linnaeus, 1758

Leptochela pugnax De Man, 1916

Liocarcinus depurator Linnaeus, 1758 
TABLE 2 (Continued)

Occurrence of the epifaunal species found at shallow waters $(5 \mathrm{~m}$, and $10 \mathrm{~m})$ and deep waters $(\leq 50 \mathrm{~m}$, and $>50 \mathrm{~m})$

Liocarcinus vernalis Risso, 1816

\begin{tabular}{ccrr} 
& \multicolumn{2}{c}{ Depth } \\
$5 \mathrm{~m}$ & $10 \mathrm{~m}$ & $\leq 50 \mathrm{~m}$ & $>50 \mathrm{~m}$ \\
+ & + &
\end{tabular}

Metapenaeus monoceros Fabricius, 1798

Erugosquilla massavensis Kossmann, 1880

Pagurus cuanensis Bell, 1845

Parapenaeus longirostris Lucas, 1846

Pisa armata Latreille, 1803

Aegaeon cataphractus Olivi, 1792

Portunus hastatus Linnaeus, 1767

Portunus pelagicus Linnaeus, 1758

Processa edulis Risso, 1816

\section{Pycnogonida/Species}

Anoplodactylus sp.

\section{Echinodermata}

Amphiura chiajei Forbes, 1843

Antedon mediterranea de Lamarck, 1816

Astropecten irregularis Pennant, 1777

Astropecten jonstoni Delle Chiaje, 1827

Ophiura albida Forbes, 1839

Ophiura sp.

\section{Nemertini/Species}

Nemertini

\section{Polychaeta/Species}

Ampharatidae (sp.)

Amphictene auricoma O.F. Müller, 1776

Amphicteis gunneri M. Sars, 1835

Chone collaris Langerhans, 1881

Chone sp.

Euclymene gracilis

Glycera unicornis Savigny in Lamarck, 1818

Glycera convoluta Keferstein, 1862

Hydroides heterocerus Grube, 1868

Hydroides norvegicus Gunnerus, 1768

Hydroides sp.

Levinsenia gracilis Tauber, 1879

Malmgrenia sp. 
TABLE 2 (Continued)

Occurrence of the epifaunal species found at shallow waters $(5 \mathrm{~m}$, and $10 \mathrm{~m})$ and deep waters $(\leq 50 \mathrm{~m}$, and $>50 \mathrm{~m})$

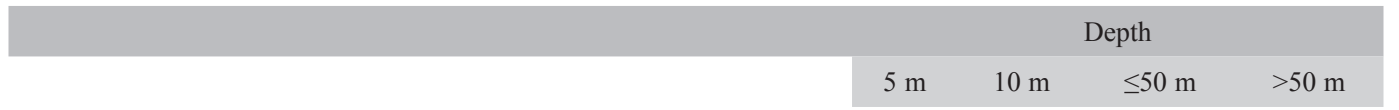

Monticellina heterochaeta Laubier, 1961

Nephtys incisa Malmgren, 1865

Nereidae sp.

Nereis sp.

Notomastus aberans Day, 1957

Onuphis conchylega Sars, 1835

Ophelina cylindricaudatus

Phyllodocidae sp.

Polyodontes sp.

Pomatoceros triqueter Linnaeus, 1767

Prionospio ehlersi Fauvel, 1928

Prionospio saccifera Mackie \& Hartley, 1990

Prionospio sp.

Scoloplos armiger Müller, 1776

Serpulidae sp.

Spirorbis sp.

Sternaspis scutata Ranzani, 1817

Terebellides sp.

Terebellides stroemii Sars, 1835

Vermiliopsis infundibulum Philippi, 1844

\section{Ascidiacea/Species}

Ciona intestinalis Linnaeus, 1758

Molgula manhattensis De Kay, 1843

\section{Sipuncula/Species}

Onchnesoma steenstrupi Koren \& Danielssen, 1875

Sipuncula sp1.

Sipuncula sp2.

\section{Anthozoa/Species}

Pennatula rubra Ellis, 1761

Actinia cari Delle Chiaje, 1825

Species marked with $*$ are alien species for the Mediterranean Sea. 
numbers of species varied between 1 and 19 species (Fig. 2). At the $5 \mathrm{~m}$ depth contour, the minimum number of species was found during two months: in March when water temperature started to rise; and October/November when the temperature started to decline. In August/ September 2000, the number of species was at a maximum, and then dropped abruptly to a minimum in October (Fig. 2A). Frequencies of occurrence (FO) were $55 \%$ for molluscs, $27 \%$ for fishes, $12 \%$ for crustaceans and $5 \%$ for echinoids. Frequent species included: $C$. persicus (10\%) and Murex trunculus (8\%) from Mollusca, Bothus podas (8\%) and $A$. laterna $(8 \%)$ from fishes, D. pugilator $(6 \%)$ and Balanus sp. (3\%) from crustaceans and $A$. irregularis (4\%) and Astropecten jonstoni (2\%) from echinoids.

The same seasonal patterns were observed at the $10 \mathrm{~m}$ depth contour (Fig. 2B). The most abundant species were $C$. persicus, A. laterna and $M$. trunculus. A hermit crab, D. pugilator and a fish, B. podas were abundant. Molluscan presence was significantly correlated with the presence of fish and Crustaceans (Spearman, $\mathrm{N}=20, \mathrm{p}<0.05$ ). Compared to the $\mathrm{FO}$ at 5 $\mathrm{m}$, only the molluscan FO reduced to $46 \%$ whereas fishes' increased to $39 \%$ at $10 \mathrm{~m}$. The dominant species were C. persicus (16\%), M. trunculus $(10 \%)$ and $M$. brandaris $(7 \%)$

$\square$ Fish $\square$ Mollusca $\square$ Crustacea $\mathbf{E}$ Echinodemata

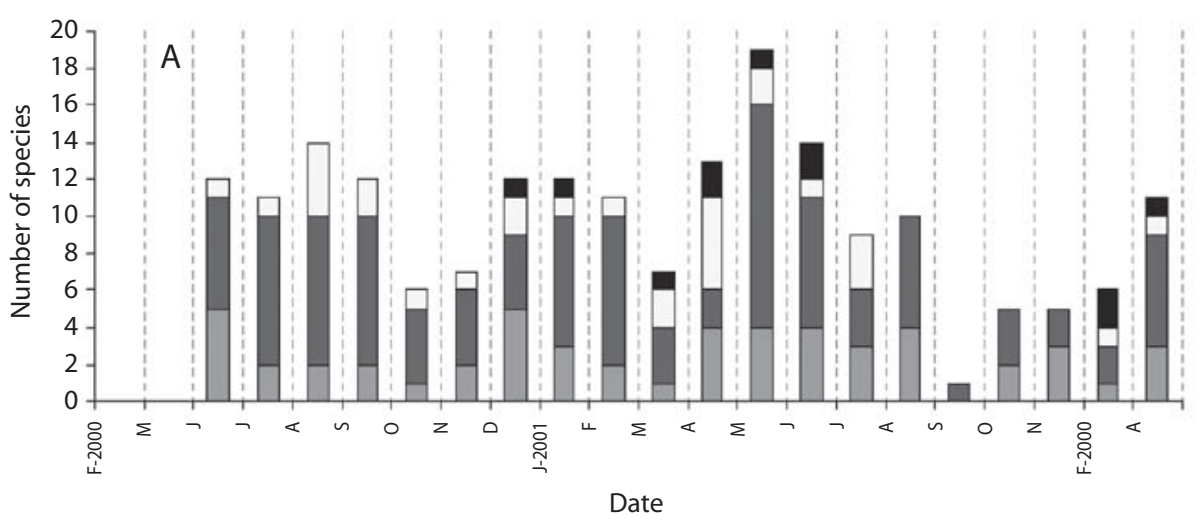

$\square$ Fish $\square$ Mollusca $\square$ Crustacea $\mathbf{n}$ Echinodemata

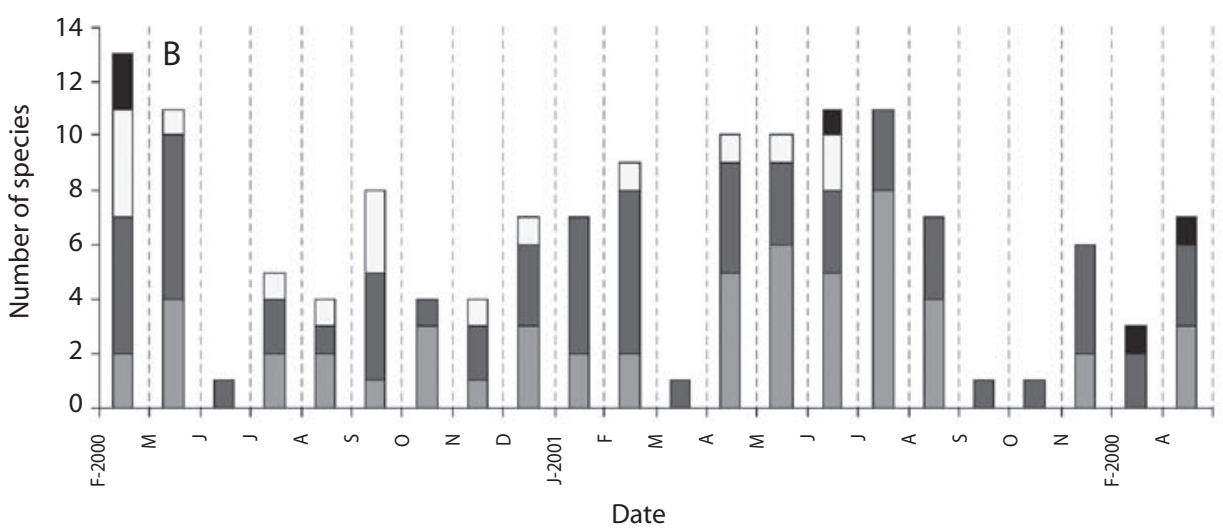

Fig. 2. Monthly distribution of number of species of dominant epifaunal taxa in the shallow waters (A.) at $5 \mathrm{~m}$ depth; and (B.) at $10 \mathrm{~m}$ depth from February 2000 to April 2002. 
from molluscans, B. podas (7\%) and A. laterna (11\%) from fishes, Goneplax rhomboides (2\%), D. pugilator (1\%) and Balanus sp. (4\%) from crustaceans and A. irregularis (2\%) from echinoids.

Abundance: The most abundant taxon was molluscs, mainly a strombid species, $C$. persicus $(78 \%)$, followed by $D$. pugilator $(15 \%)$ and $B$. podas (1\%). Conomurex persicus $(65 \%)$. D. pugilator comprised $28 \%$ of the total abundance at $5 \mathrm{~m}$ whereas $C$. persicus contributed $94 \%$ to the total at $10 \mathrm{~m}$ depth. $C$. persicus and D. pugilator were mainly predominant in winter and summer. There was inter-annual variation in the abundance due to variability of water temperature and salinity. At $5 \mathrm{~m}$ the highest abundances $\left(>1\right.$ ind $\left.\mathrm{m}^{-2}\right)$ were during spring (March) and early autumn (October) while the lowest abundances $(<1$ ind $\mathrm{m}^{-2}$ ) were observed during November to February whereas at $10 \mathrm{~m}$, between April and September and between October and March, respectively (Fig. 3A, C, E, G). Molluscan species (C. persicus and M. trunculus) and flatfish species, (A. laterna and B. pothas) were most abundant in spring and autumn (Fig. 3A, C). Astropecten irregularis was the most abundant echinoid species. Abundance of crustacean species was significantly positively correlated with that of fish (Spearman $\mathrm{r}=0.60, \mathrm{t}_{\mathrm{N}-2}=3.18, \mathrm{~N}=$ 20, $\mathrm{p}=0.005$ ), but negatively with molluscans at $5 \mathrm{~m}$ depth contour (Spearman $\mathrm{r}=-0.47, \mathrm{t}_{\mathrm{N}-2}=$ $-2.24, \mathrm{~N}=20, \mathrm{p}=0.038$ ).

Biomass: Biomass was dominated by molluscs, of which $C$. persicus contributed $97 \%$ to the total biomass (Fig. 3D). Biomass greater than $20 \mathrm{~g} \mathrm{~m}^{-2}$ (mostly, molluscans) occurred during April-October. The next highest contributors to biomass were $M$. trunculus $(0.78 \%), B$. podas $(0.47 \%)$, D. pugilator $(0.12 \%)$ and $A$. irregularis $(0.01 \%)$. Fish biomass increased from March to June, and then reached its minimum in October at $5 \mathrm{~m}$ and in September at $10 \mathrm{~m}$ (Fig. 3B). The biomass peaked again in January. Crustacean and echinoid biomass showed similar trends to fish except winter condition (Fig. 3F,H). During year 2000, crustacea was positively correlated with fish (Spearman $\mathrm{r}=0.47, \mathrm{t}_{\mathrm{N}-2}=2.24, \mathrm{~N}=$ $20, p=0.038$ ), and negatively with mollusca in terms of biomass (Spearman $\mathrm{r}=-0.60, \mathrm{t}_{\mathrm{N}-2}=$ $-3.18, \mathrm{~N}=20, \mathrm{p}=0.005)$.

Diversities: In general, the diversity indices showed spatial and temporal differences. At $5 \mathrm{~m}$ the indices peaked in December and MayJune (Fig. 5) whereas they had minimum values in March and October-November: In March, the lowest species diversity was associated with one fish, 3 molluscs, 2 crustaceans and 1 echinoid. In May-June, the highest diversities occurred with five fishes (B. podas and Solea lascaris most common species), 14 molluscs (M. brandaris, Nassarius gibbosulus, N. mutuabilis, Nayitopsis grannum most common), 2 crustacean (D. pugilator and Liocarcinus vernalis) and 2 echinoid (A. irregularis and $A$. jonstoni) at $5 \mathrm{~m}$.

The diversity indices at $10 \mathrm{~m}$ peaked in December-February and June/July. High diversity continued for 3 months during the winter, in contrast to one month duration at $5 \mathrm{~m}$. The diversity minima occurred during spring from March-May and during summer from AugustOctober (Fig. 5). Diversity indices increased when several fishes (B. podas, Trachinus draco and $S$. lascaris), molluscs (M. brandaris, $M$. trunculus, P. radiata and Sepia officialis), and crustaceans (G. rhomboides) contributed. The summer peak occurred in association with 16 fish species. There were only 5 species of fish during the spring diversity minimum and 6 species during the autumn minimum (AugustOctober).

\section{Deep water}

Species richness: The total number of species, including fish, increased from winter ( 7 species) through spring and summer (37 and 34 species) to autumn (63 species, Table 2). In February, the number of fish species was as low as that in November (2 species), peaked in May (9 species), and then decreased from spring to 

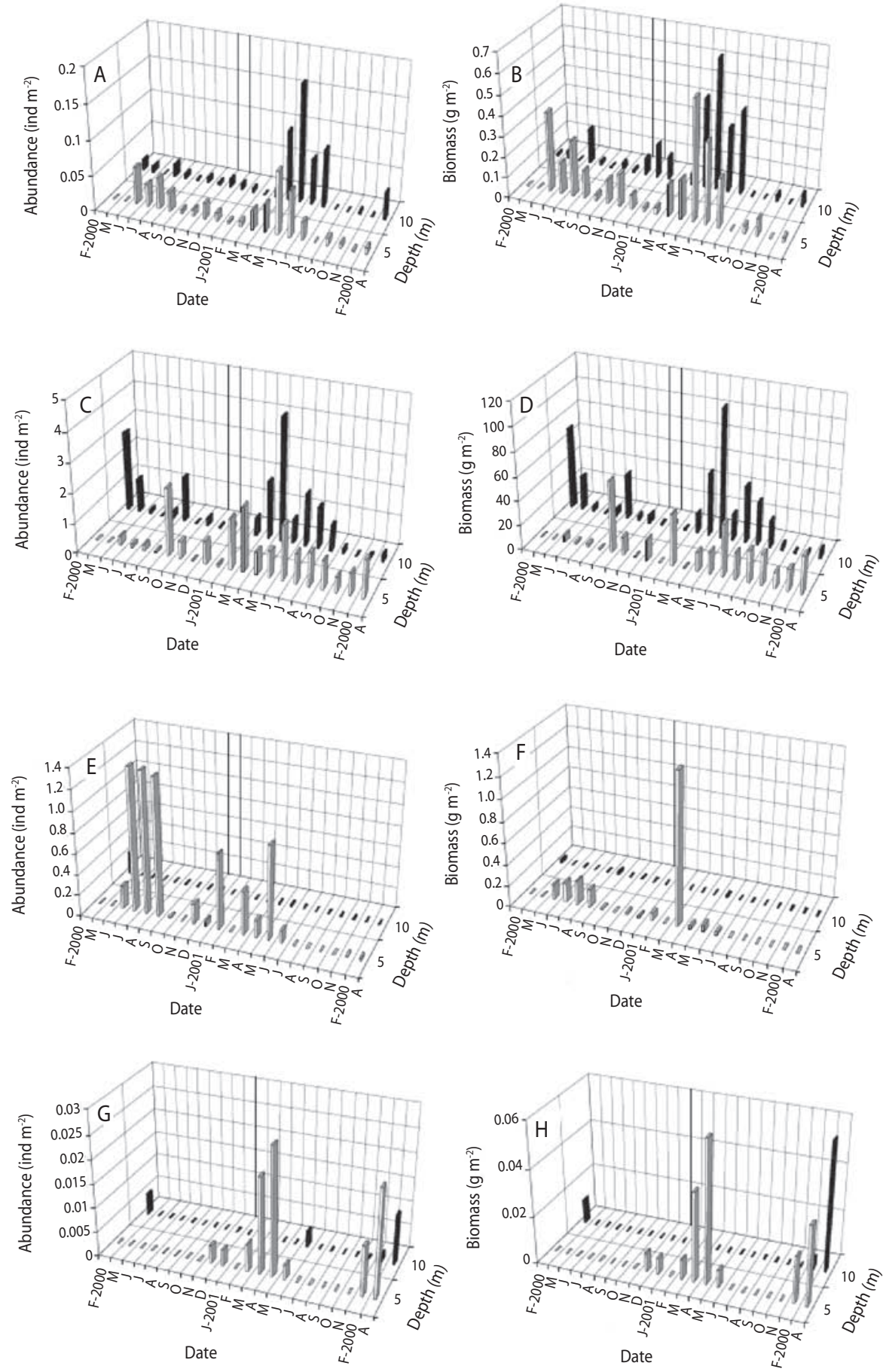

Fig. 3. Spatial distribution of abundance and biomass of epifaunal taxa: Fish (A.-B.), Mollusca (C-D), Crustacea (E-F) and Echinodermata (G-H) in the shallow waters in months from February 2000 to April 2002. 
autumn (Fig. 4A). A. laterna was observed in all seasons whereas Gobius sp. and Apogon nigripinis were found only in February, Trigla and Gobius spp. were found in May and Mullus sp. and Saurida sp. were found in August. The number of echinoids varied from 1 (February and May) to 3 (November; Fig. 4J). The sea star, A. irregularis was recorded in February while $A$. chiajei was found in August. A bristle star, Ophiuroidae sp. was recorded in May.
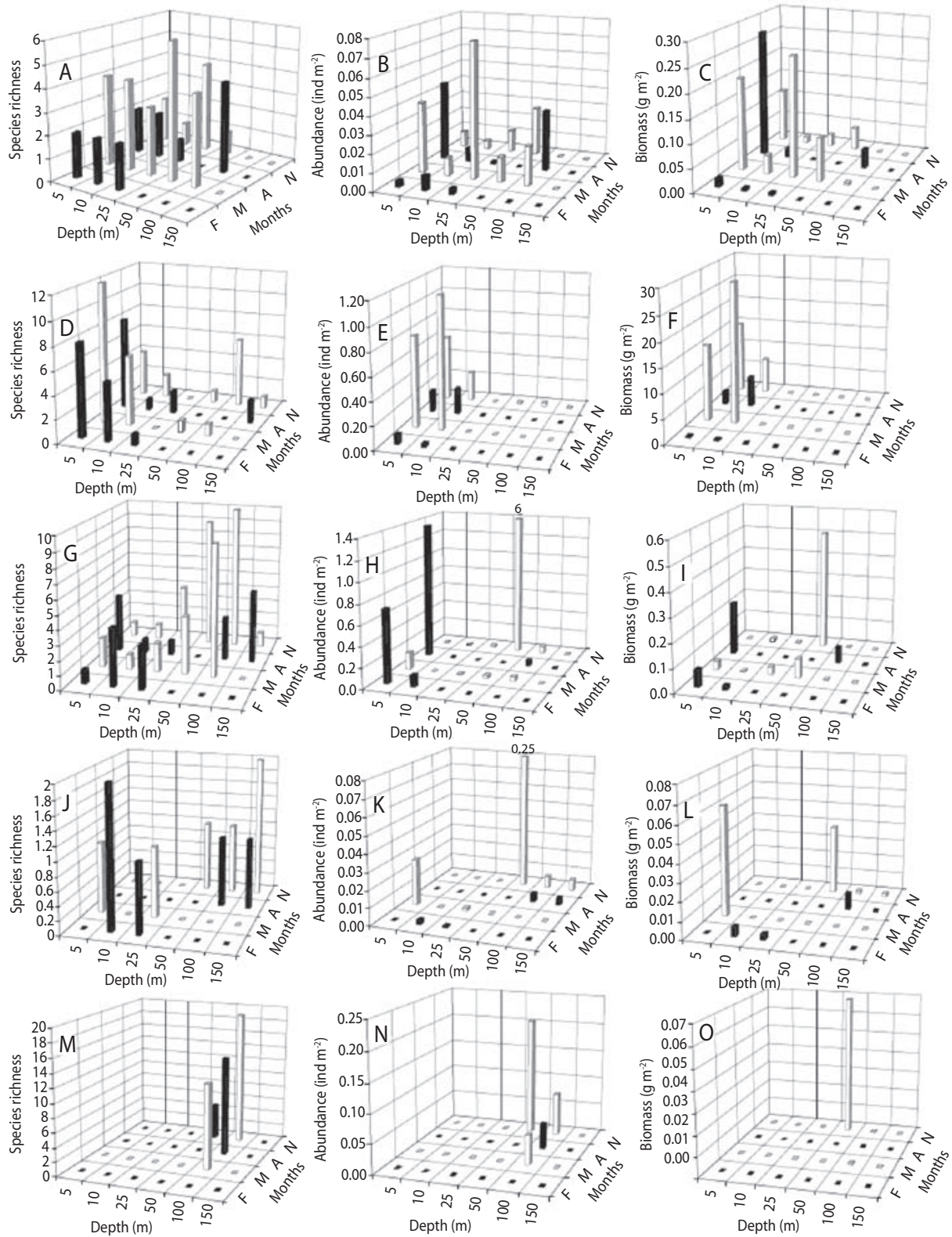

Fig. 4. Spatio-temporal distribution of species richness, abundance and biomass of epifaunal taxa: Fish (A-C), Mollusca (D-F), Crustacea (G-I), Echinodermata (J-L) and Polychaeta (M-O) in the deep waters with 5 and 10 m included in February (F), May (M), August (A) and November (N) during year 2000. 
Antedon mediterranea were observed for the first time of the dredge study in November. Molluscan species increased from winter (1) to autumn (9 species, Fig. 4D) and the species composition was highly variable among seasons. However, there was no predominate molluscan species. Overall, the number of crustacean species increased from February (3 species) through May and August (9-12 species) to November (22 species, Fig. 4G). Alpheus glaber, G. rhombodies, D. pugilator and $P$. longirostris were found in all seasons whereas Erugosquilla massavensis was observed in warm seasons (May and August). The number of Polychaeta species doubled between May (12 species) and November (24 species) and no polychaetes were observed in February (Fig. 4M). In general, Prionospio sp. was observed in all seasons.

Species richness of fish seemed to increase with depth and peaked at 50 and $100 \mathrm{~m}$ (Fig. 4A). Contrasted to the crustaceans (Fig. 4G), number of molluscan species decreased with the bottom depth (Fig. 4D). Echinoids showed peaks at two depths: $25 \mathrm{~m}$ in February and May and 100-150 m (Fig. 4J) in August and November.

Abundance: Abundance increased from 0.17 ind $\mathrm{m}^{-2}$ in winter (February) to $\sim 7$ ind $\mathrm{m}^{-2}$ in autumn (November). Abundances of Crustacea increased from winter to autumn (Fig. 4H). The echinoid abundances remained in minimum during winter-summer and then increased abruptly in autumn as the same occurred for polychaetes (Fig. 4K, N). Molluscan abundances showed a reverse distribution with those of fishes (Fig. 4E). The most abundant species were $D$. pugilator comprising $79 \%$ of the total abundance $\left(7.6\right.$ ind $\mathrm{m}^{-2}$ ), A. chiajei $3.3 \%$ and A. laterna $2.3 \%$ and $G$. rhomboides $1 \%$. Seasonally, the most abundant species were: in winter, C. persicus (40\%) and A. laterna $(20 \%)$; in spring, Arnoglossus species (47\%) and $P$. longirostris (6\%); in summer, Arnoglossus laterna (12\%) and G. nijer jozo (7\%); and in autumn D. pugilator (84\%). Crustacean abundances were positively correlated with those of fish whereas polychaetes were positively correlated with Echinodermata, Anthozoa, Sipuncula and Scapopoda (Spearman, $\mathrm{N}=4, \mathrm{p}<0.05$ ). The abundance of crustaceans was positively correlated with Polychaeta abundance, while Anthozoa abundance was negatively correlated with fish and positively with Echinodermata (Spearman, $\mathrm{N}=20, \mathrm{p}<0.05$ ).

Spatio-temporal quantitative distributions of the epifaunal taxa were as follows: In February, abundancees of fish, crustacean and echinoid were low $\left(<0.004\right.$ ind $\left.\mathrm{m}^{-2}\right)$ at 25 $\mathrm{m}$ depth whereas molluscan's was 0.004 ind $\mathrm{m}^{-2}$ (Fig. 4B, E, H, K). In May, taxa found at each depth were fish and Crustacea. The other taxa were observed at different depths (Fig. $4 \mathrm{~K}, \mathrm{~N})$. Fish abundance decreased from 0.07 ind $\mathrm{m}^{-2}$ at $25 \mathrm{~m}$ to $\sim 0.02$ ind $\mathrm{m}^{-2}$ at $100 \mathrm{~m}$ (Fig. 4B). In August, species of some groups (Echinodermata, Cnidaria, and Polychaeta) started to appear at depth $\geq 100 \mathrm{~m}$. Crustacean abundance varied between 0.001 and 0.05 ind $\mathrm{m}^{-2}$ (Fig. 4H), fish between 0.001 and 0.03 ind $\mathrm{m}^{-2}$ (Fig. 4B), and Mollusca between 0.002 and 0.005 ind $\mathrm{m}^{-2}$ (Fig. 4E). In November, abundance of the taxa changed increasingly seaward up to $\sim 50 \mathrm{~m}$ and then decreasingly in the deeper waters. Species of some groups (Sipuncula, Cnidaria, Echinodermata, Scaphopoda) started to appear at depths greater than $50 \mathrm{~m}$ at which fish disappeared. Fish abundance varied between 0.01 and 0.03 ind $\mathrm{m}^{-2}$ (Fig. 4B) molluscan between 0.001 and 0.03 ind $\mathrm{m}^{-2}$ (Fig. $4 \mathrm{E})$. Crustacean abundances changed increasingly from 0.02 at $25 \mathrm{~m}$ to 6 ind $\mathrm{m}^{-2}$ at $50 \mathrm{~m}$ (Fig. 4H).

Biomass: In February, biomass of fish, crustacean and echinoid were low $(<0.005 \mathrm{~g}$ $\mathrm{m}^{-2}$ ) at $25 \mathrm{~m}$ depth (Fig. 4C, I, L) whereas molluscan's was $0.14 \mathrm{~g} \mathrm{~m}^{-2}$ (Fig. 4F). In May, taxa found at each depth were fish and Crustacea. The other taxa were observed at different depths. Fish biomass decreased from $0.25 \mathrm{~g} \mathrm{~m}^{-2}$ at $25 \mathrm{~m}$ to $0.005 \mathrm{~g} \mathrm{~m}^{-2}$ at $100 \mathrm{~m}$ (Fig. 4C). In August, Crustacean abundance varied between 0.0009 and $0.06 \mathrm{~g} \mathrm{~m}^{-2}$ (Fig. 4I), fish between 0.001 and $0.04 \mathrm{~g} \mathrm{~m}^{-2}$ (Fig. 4C) and Mollusca 
between 0.01 and $0.002 \mathrm{~g} \mathrm{~m}^{-2}$ (Fig. 4F). In November, biomass of most taxa peaked at 50 $\mathrm{m}$ and then was tended to decrease seaward. Crustacean biomass peaked $\left(0.51 \mathrm{~g} \mathrm{~m}^{-2}\right)$ at 50 m (Fig. 4I) was contributed by a hermit crab, $D$. pugilator, with a biomass of $0.49 \mathrm{~g} \mathrm{~m}^{-2}$

Diversities: The species diversities in deep water were related to depth and season. There were two peaks in diversity during spring (May) and autumn (November), at all depths (Fig. 5). Low diversity was observed in winter (February) and summer (August). Overall, species diversity increased from $25 \mathrm{~m}$ to $100 \mathrm{~m}$ and then declined at $150 \mathrm{~m}$ (Fig. 5). At $25 \mathrm{~m}$, the diversity was moderate in winter and autumn when the temperatures were stable at $\sim 18{ }^{\circ} \mathrm{C}$, but in spring and summer when the temperatures were highly variable $\left(16-30{ }^{\circ} \mathrm{C}\right)$, this depth had the lowest diversity. At $25 \mathrm{~m}$ in May, 3 fish, 2 crustacean and one echionoid species were recorded and subsequently the diversity declined due to abundant fishes moving into the area. In November, 4 species of fish and 4 species of Crustaceans were found at 25 $\mathrm{m}$ with equal abundances. Therefore, species richness was relatively low, while evenness and diversity indices were high. At $50 \mathrm{~m}$, there was an abrupt decrease in the indicies. Two abundant species, D. pugilator $\left(6\right.$ ind $\left.\mathrm{m}^{-2}\right)$ and A. chiajei $\left(0.3\right.$ ind $\left.\mathrm{m}^{-2}\right)$ here reduced the diversities. At $100 \mathrm{~m}$, equal abundance of several species caused increased species evenness and diversity, mainly because of the abundance of crustaceans and polychaetes (Fig. 5). At about $150 \mathrm{~m}$, there were no fish or polychaetes, but 2 molluscs, 5 crustaceans and 1 echinoid were found. Their abundances were less than 0.004 ind $\mathrm{m}^{-2}$ at this zone.

\section{Ordination of samples}

Multidimensional scaling showed that species clusters (Fig. 6A, D) were mainly related to bottom depths (Fig. 6A) and total organic carbon content (TOC; Fig. 6C) of the sediment and slightly to silt content (Fig. 6B). Epifauna in shallow water was different than that in the deep water (Fig. 6A). The shallow waters had TOC content less than $0.3 \%$ while the TOC in the deep waters varied between $0.5 \%$ and $0.8 \%$ (Fig 6C). Distribution of silt content was $<1 \%$ in the shallow waters and $>10 \%$ in the deep waters (Fig. 6B). Analysis of similarity (ANOSIM) showed that the deep waters differed significantly (Confidence limits of p; $0.03-1.16 \%$ at 95 percent) from the shallow

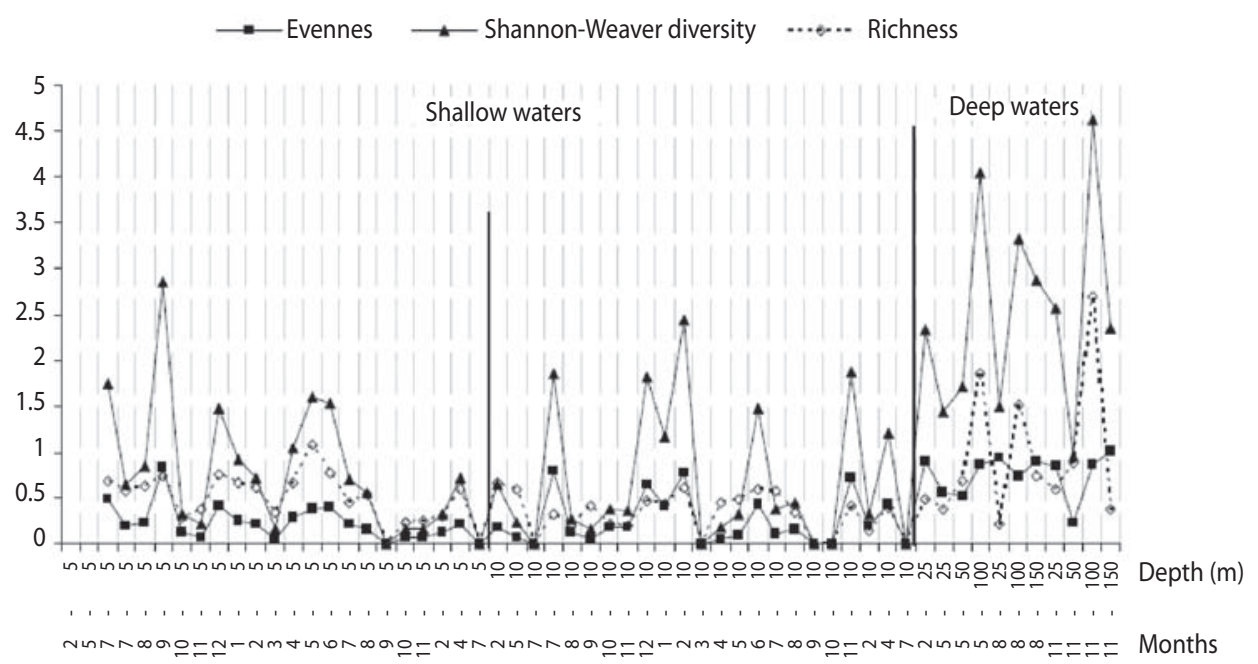

Fig. 5. Spatio-temporal distributions of the diversity indices (Margalef's richness, Pielou evenness and Shannon-Weiner diversity) in the shallow and deep waters of the Cilician shelf. 

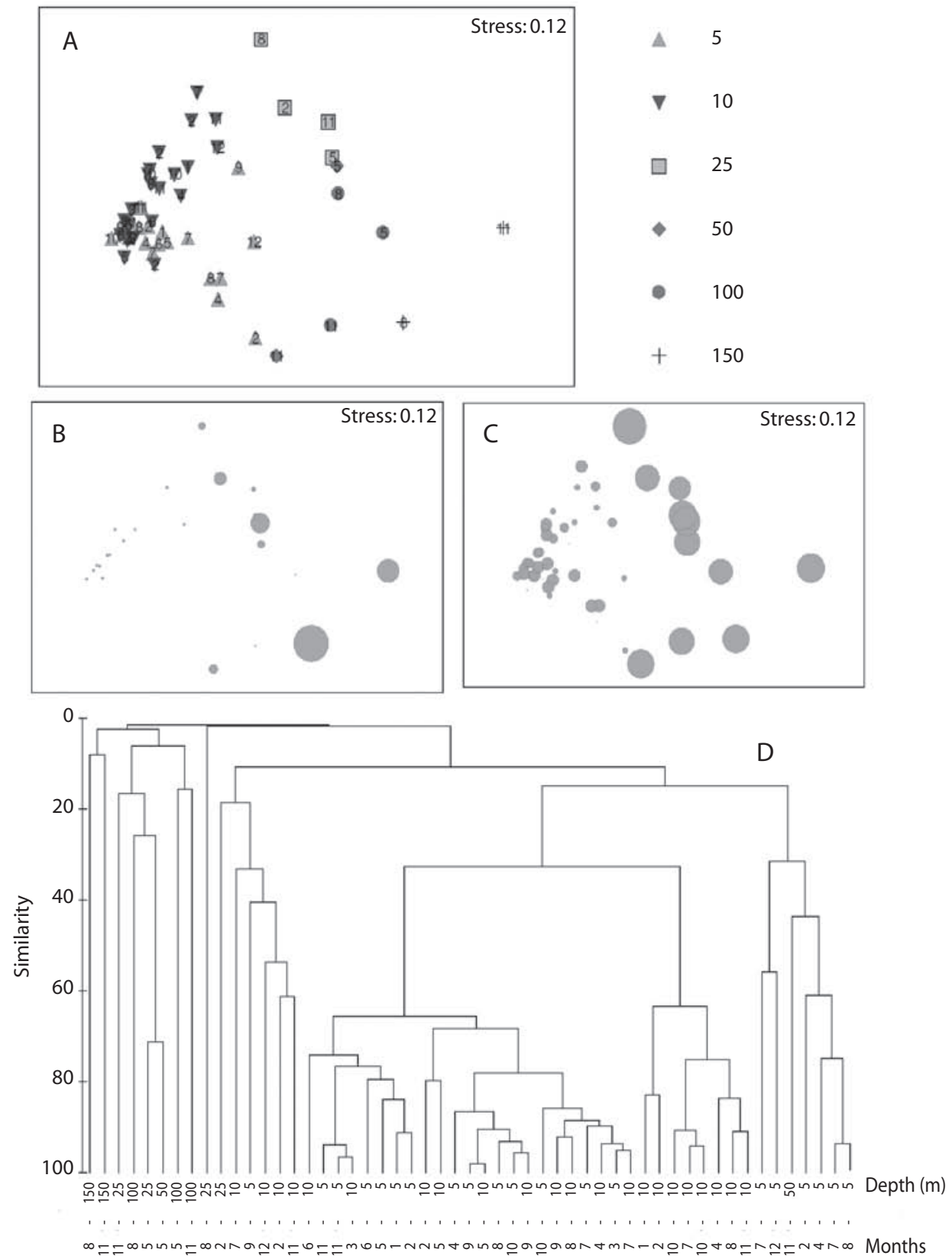

Fig. 6. Cilician shelf epifauna. A. MDS of species abundance with superimposed different symbols representing bottom depth. Number on the symbol denotes the sampling months, and sedimentary parameters of the sampling locations with superimposed circles representing silt content (B) and TOC, total organic content (C). Dendogram for hierarchical clustering of the stations, using group-average linking of Bray-Curtis similarities calculated on $\log _{10}(\mathrm{X}+1)$ transformed abundance data $(\mathrm{X})$ of the shallow and deep waters (D). 
waters in species abundance and composition (Table 3). In the shallow water, C. persicus $(92 \%)$ and D. pugilator (3\%) contributed most to the total similarity (Table 3 ). In the deep waters, those were A. laterna $(45 \%)$ and $D$. pugilator (18\%) (Table 3). The presence of $C$. persicus $(58 \%)$ mainly discriminated between the waters while other species such as $D$. pugilator, A. laterna, G. rhomboides, B. podas and $M$. trunculus discriminated to a smaller degree (Table 3).

The canonical plot is extremely informative as it shows there were real differences in the epifaunal assemblages at the three different depth sites (Fig. 7). Squared canonical correlations were 0.953 and 0.516 and using $\mathrm{m}=15$ explained $97.03 \%$ of total variation and resulted in the smallest cross-validation error $(18.87 \%)$. All the test statistics resulted in the highly significant results with 9999 permutations $(p=0.000)$, indicating strong evidence against the null hypothesis which is no difference in the epifaunal assemblages in the three depth sites. The test showed that there were no significant differences in the epifaunal assemblages inbetween years 2000 and 2001 at both depth contours of $5(\mathrm{p}=0.058)$ and 10 $\mathrm{m}(\mathrm{p}=0.496)$ whereas significant seasonal differences were found with 9999 permutations $(\mathrm{p}=0.04)$. The seasonal difference was not

TABLE 3

Contributor species in the shallow and deep waters and discriminator species between the zones

\begin{tabular}{|c|c|c|c|c|}
\hline Species & Av Sim & Ratio & Percent & Cum $\%$ \\
\hline \multicolumn{5}{|c|}{ GROUP I (Shallow waters) AvSim: 33.74, S.D.: 29.435} \\
\hline Conomurex persicus $*$ & 31.0 & 1.05 & 92.03 & 92.03 \\
\hline Diogenes pugilator & 1.0 & 0.15 & 3.07 & 95.10 \\
\hline Arnoglossus laterna & 0.4 & 0.11 & 1.08 & 96.18 \\
\hline Bothus podas & 0.3 & 0.10 & 0.99 & 97.17 \\
\hline Murex turunculus & 0.2 & 0.06 & 0.58 & 97.75 \\
\hline \multicolumn{5}{|c|}{ GROUP II (Deep waters) AvSim: 9.91, S.D.: 14.646} \\
\hline Arnoglossus laterna * & 4.4 & 0.34 & 44.86 & 44.86 \\
\hline Goneplex rhomboides * & 1.8 & 0.45 & 18.05 & 62.91 \\
\hline Parapenaeus longimanus & 0.4 & 0.34 & 3.81 & 66.72 \\
\hline Alpheus glaber & 0.3 & 0.28 & 3.50 & 70.22 \\
\hline Gobius niger jozo & 0.3 & 0.19 & 3.46 & 73.68 \\
\hline
\end{tabular}

Av Dis (Grps II \& I): 98.43, S.D.: 2.983. R: 1, p: 19.618 (0.200 \%), Approx. 95\% C.I. is (0.03\%-1.16\%)

$\begin{array}{lcccc}\text { Species } & \text { Av Dis } & \text { Ratio } & \text { Percent } & \text { Cum\% } \\ \text { Conomurex persicus ** } & 57.21 & 1.75 & 58.12 & 58.12 \\ \text { Diogenes pugilator } & 10.48 & 0.47 & 10.65 & 68.77 \\ \text { Arnoglossus laterna } & 5.47 & 0.50 & 5.55 & 74.32 \\ \text { Goneplex rhomboides } & 2.72 & 0.44 & 2.77 & 77.09 \\ \text { Bothus podas } & 1.87 & 0.53 & 1.90 & 78.99 \\ \text { Murex turunculus } & 1.20 & 0.44 & 1.22 & 80.21 \\ \text { *, contributor species, } & & & \\ \text { **, discriminator species. } & & & \\ \text { AvSim: Average similarity; Cum\%: Cumulative percent dis/similarity; S.D.: Standard deviation of dis/similarity, R: } \\ \text { ANOSIM R statistic; Av Dis: Average dissimilarity, Approx. 95\% C.I: Approximate Confidence interval at 95\% level. }\end{array}$



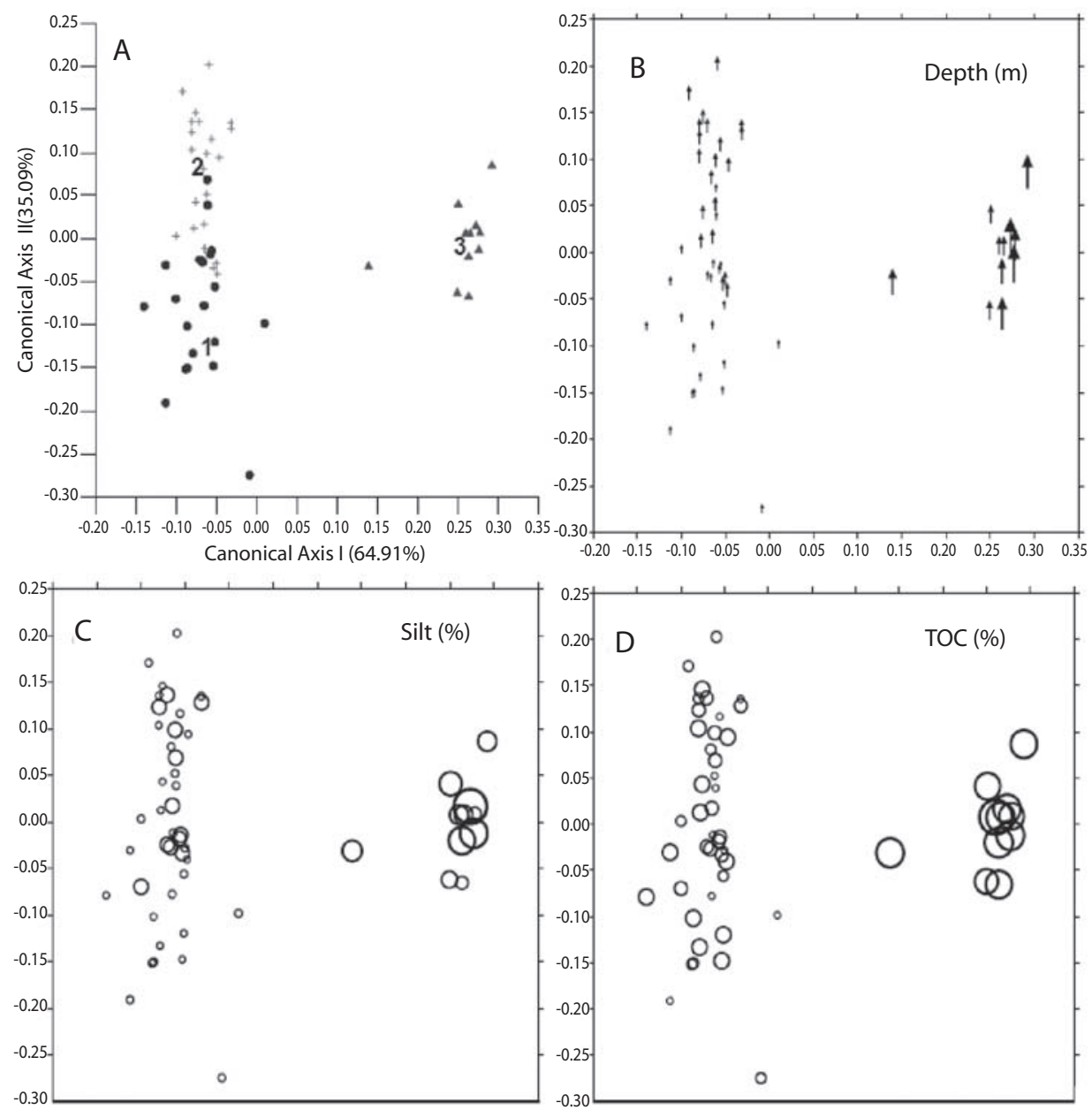

Fig. 7. A. Ordinations of the multivariate epifaunal species abundance data from shallow and deep waters in the Cilician shelf using generalized canonical analysis (CAP), $m=15$. For the plot, the data were first $\log _{10}$-transformed and the BrayCurtis dissimilarity was calculated between all pairs of observations; and (B.) schematic representation of bottom depth; (C.) silt content of the sediment; and (D.) total organic carbon superimposed on the CAP (1 marked with circle full: $5 \mathrm{~m}$; 2 marked with +: $10 \mathrm{~m} ; 3$ marked with triangle: $25-150 \mathrm{~m}$ ).

significantly observed as results of canonical correlation analyses (generalized discriminant analyses) applied for the epifaunal abundance depth contours between $25 \mathrm{~m}$ and $155 \mathrm{~m}$ (Table 4). Similar to the nMDS (Fig. 6), ordination of CAP (Fig. 7A) was correlated mainly with bottom depth (Fig. 7B), TOC (Fig. 7D) and silts content of the sediments (Fig. 7C).

\section{DISCUSSION}

Depth and substrate were important factors influencing the structure of the macroepibenthic fauna. Two distinct epibenthic communities were identified on the basis of species distribution. The first was found at shallow depths $(\leq 10$ $m$ with "fine, well-sorted sand" (SFBC, Peres 
TABLE 4

Results of cross-validation and permutation test for depth, interannual, seasonal groups of the epifaunal assemblages

a) Depthwise $(\mathrm{m}=\mathbf{1 5})$; Total correct: $81.13 \% ; \mathrm{p}=\mathbf{0 . 0 0 0}$

$\begin{array}{cccccc} & 5 \mathrm{~m} & 10 \mathrm{~m} & 25-155 \mathrm{~m} & \text { Sample size } & \% \text { correct } \\ 5 \mathrm{~m} & 17 & 3 & 0 & 20 & 85.00 \\ 10 \mathrm{~m} & 6 & 16 & 0 & 22 & 72.73 \\ 25-155 \mathrm{~m} & 1 & 0 & 10 & 11 & 90.91\end{array}$

b) Interannual at $5 \mathrm{~m}$; $(\mathrm{m}=1)$; Total correct: $80.00 \% ; \mathrm{p}=\mathbf{0 . 0 5 8}$

$\begin{array}{ccccc}2000 & 2001 & 7 & \\ 5 & 2 & 13 & 71.43 \\ 2 & 11 & 84.62\end{array}$

c) Interannual at $10 \mathrm{~m} ;(\mathrm{m}=4)$; Total correct: $54.55 \% ; p=0.496$

$\begin{array}{ccccc}2000 & 2001 & 7 & \\ 3 & 6 & 13 & 63.33 \\ 4 & 9 & 13.23\end{array}$

d) Seasonal at shallow $(5$ and $10 \mathrm{~m})(\mathrm{m}=5)$; Total correct: $35.71 \% ; \mathrm{p}=\mathbf{0 . 0 4 0}$

$\begin{array}{ccccccc} & \text { Summer } & \text { Autumn } & \text { Winter } & \text { Spring } & & \\ \text { Summer } & 3 & 2 & 2 & 5 & 12 & 25.00 \\ \text { Autumn } & 4 & 3 & 2 & 3 & 12 & 25.00 \\ \text { Winter } & 3 & 1 & 4 & 1 & 9 & 44.44 \\ \text { Spring } & 3 & 1 & 0 & 5 & 9 & 55.56\end{array}$

e) Seasonal at deep $(25-155 \mathrm{~m})(\mathrm{m}=7)$; Total correct: $40.00 \%$; $=\mathbf{0 . 5 5 9}$

$\begin{array}{cccccc} & \text { Spring } & \text { Summer } & \text { Autumn } & & \\ \text { Spring } & 2 & 0 & 1 & 3 & 66.67 \\ \text { Summer } & 0 & 0 & 3 & 3 & 00.00 \\ \text { Autumn } & 0 & 2 & 2 & 4 & 50.00\end{array}$

Rows are true groups, columns are predicted groups.

$\mathrm{m}=$ number of axes.

1982a). In particular, the community inhabiting $10 \mathrm{~m}$ can be ascribed to the Fine Sands slightly muddy (Makra and Nicolaidou 2000, Gusso et al. 2001). The $5 \mathrm{~m}$ community was similar to that found at $10 \mathrm{~m}$, although it had a lower number of species. Community at deep zone was ascribable to the Muddy-Detritic community (DE, Peres 1982b), being composed mainly of mud, sand and detritus dwelling species. The absences of seagrass around the study area could change depth limit $(25 \mathrm{~m})$ of SFBC as the depth was ascertained as $40 \mathrm{~m}$ for the
Mediterranean Sea (Peres 1982b, Gusso et al. 2001). Beyond $40 \mathrm{~m}$ depth, the hydrodynamic process become less effective therefore the bottom sediments are virtually at rest. In this area the presence of bio-detrital deposits (molluscan shells and calcareous algae) induces a source of variability in the sediment composition down to $100 \mathrm{~m}$ as the same was found by Karakassis and Eleftheriou (1998) in Cretan shelf.

The community composition was largely the result of the considerable number of species represented by few individuals, but most 
abundant species (C. persicus, $M$. trunculus and $M$. brandaris with $\sim 5$ ind $\mathrm{m}^{-2}$ in spring and autumn) on sand bottom of the shallower waters. Conomurex persicus is widespread over the shallow waters of the Levantine Sea after being introduced in 1978 (Nicolay and Manoja 1983, Galil and Zenetos 2002). The temporal trends showed remarkable change in contrast to no regular seasonal pattern in very shallow waters of the NE Aegean Sea (Kourelea et al. 2004) where $C$. persicus was present. The Diversity index showed a sharp decrease during February-March and October-November when the sea surface temperature started to increase or decrease after relatively stable periods. Sarda et al. (2000) showed similar general seasonal pattern in total macroinfaunal abundance of shallow sandy-bottom assemblages in the Catalan Western Mediterranean Sea as stated in German Bight (Hinz et al. 2004). In Levantine Basin of the Mediterranean Sea, these cycles were consistent with the temporal variation in several key species, especially molluscan species: Conomurex persicus could however be most reasonable species for the seasonal fluctuations of the epifaunal density (Mutlu and Ergev 2006).

In deep stations, the observed species composition conforms to the bathyal mud assemblage, similar to that of other areas of the Mediterranean and the neighboring NE Atlantic (Vamvakas 1970, Janssen 1989). The depth distribution of polychaete feeding types is directly related to the amount of organic matter available in the sediments, with surface deposit feeders strongly dominating the continental shelf. Polychaetes and Crustaceans dominated the species composition in all the samples analysed. Of the total number of species the number of polychaete species ranged from 30 to $40 \%$ over the continental shelf (25$150 \mathrm{~m}$ ) whereas Crustaceans slightly decreased with depth ranging from 20 to $35 \%$ in year 2000. Tselepides et al. (2000) found similar trend for two taxa (Polychaeta: 45.56 to $49.04 \%$ and Crustaceans 21.48 to $18.47 \%$ ) over the continental shelf $(40-200 \mathrm{~m})$ in the Cretan Sea. Molluscs in general remained a relatively stable (10-20\%) in both Cretan Sea self and Cilician basin self as it was the same in Northern Aegean Sea (NCMR 2001, UNEP/ MAP 2004). Smith et al. (2000) showed that before the trawling season, the trawl lane was numerically dominated by the Crustacea $(85 \%)$, while after the trawling season the composition had become much more even. In contrast, the control area was dominated by the Echinodermata (80\%) in the Cretan waters. In November 2000, abundance of Echinodermata was observed to increase $(10 \%)$ in the Cilician shelf after trawling season. Contrast to polychaetes and fishes, density dominance of crustaceans increased from $20 \%$ by starting of trawl season (May-September) to $80 \%$ during mid and post trawl season. However, Tselepides et al. (2000) found the similar depthwise trend whilst Polychaetes with 45 to $70 \%$ contribution were most abundant group in the Cretan self.

It is interesting to note that stations at 10 $\mathrm{m}$, are placed in both clustering and the MDS closer to the group of stations sampled at $5 \mathrm{~m}$. An examination of the values of abundance $(\mathrm{N})$, species (S) and diversity (H') indices per sample shows that they are significantly higher for samples taken at $5 \mathrm{~m}$, while Evenness $\mathrm{J}$ is slightly higher for samples at $10 \mathrm{~m}$. The presence of Chamelea gallina, $N$. circumcinetus, $N$. gibbosulus, N. mutuabilis, N. josephina (molluscs), D. pugilator (crustacean that was hosted by the Nassarius molluscs) and A. irregularis (echinoids) at $5 \mathrm{~m}$ (generally found between December and June) appears to be responsible for the increased number of species and hence the high Diversity. Astropecten irregularis were responsible for the main differences between seasons in German Bight (Hinz et al. 2004). The variety of available substrata results in an increased number of microniches, and thus of diversity at the shallow waters, while the homogeneity of the substrate could be responsible for the lower diversity and higher evenness found at the deep waters (Makra and Nicolaidou 2000), resulted from the less effective hydrodynamic process (Karakassis and Eleftheriou 1998). 
Because the prevailing sandy sediments would be expected to naturally restrict the occurrence of sessile taxa, depth and sediment characteristics were the principal determinants of assemblage type. Epifaunal surveys indicate that the role of sediment type in determining the distribution of epifauna assemblages is apparently secondary to that of depth. From multivariate analyses in this study, it became evident that seasonality was not a major factor in the macrobenthic community structure. Only abundance of fish species in the shallow zone was significantly correlated as function of time series data over the sampling dates (Autocorrelation, $\mathrm{p}<0.05$ ). It is concluded that the abundance data have come from an underlying sinusoidal model over 6-month period: The correlation was negative in period between August and January and positive between February and July. In the shallower water, fish abundance increased during positive correlations period, being more pronounced between April-May. Similar species richness trends in uniform sandy areas showed similar results via clustering of abundance data over the continental margin of Crete and the study showed groupings associated with the depth not with seasons (Tselepides et al. 2000). In the North Sea, the environmental factors which account for the faunal distributions suggested that temperature variation and depth and sediment parameters were better descriptors of the epifaunal separation than absolute temperature (Jennings et al. 1999, Callaway et al. 2002). In the Mediterranean Sea water temperature over the continental shelf starts to increase in early spring and fish that winter there. After spawning most fish begin their feeding migration in summer and during autumn the massive recruitment migration occurs (Kallianiotis et al. 2000). The spatial and temporal changes in the demersal fishes of the Galician coast (Spain) are mainly associated with oceanographic phenomena displaying great seasonal and interannual variability (Farina et al. 1997b), whereas in decapods the more stable sediment and oceanographic conditions are of greater importance (Farina et al. 1997a). The CAP as well showed significant difference in seasonal epifaunal assemblages in the shallow waters whereas no seasonal significant difference was found in the deep zone (Table 4). Community changes have often been correlated to depth, but in shallow marine environments sedimentary or other physical as well as biological variables which are depthrelated are more likely to be the controlling factors than depth itself (Gray 1981, Tsutsumi et al. 1990, Fanelli et al. 2007). Tselepides et al. (2000) they stressed that species groupings are associated with the depth not with seasons over the continental margin deeper than $40 \mathrm{~m}$ in the Cretan waters. Simboura et al, (2000) considered different factors for the polychaete communities at different depths. For example, in the shallower stations (3-9 $\mathrm{m}$ ) the governing factors were substratum type and hydrodynamic conditions. In the deep waters (36-150 m) the main controlling factors were the granulometric composition of the sediment and depth. Cosentino and Giacobbe (2006) concluded that in the shallower zone $(<20 \mathrm{~m})$, a wide typology of trophic-ethological guilds was related to community patchiness, in contrast to a greater functional uniformity of the deeper assemblage (25-50m), dominated by sessile, semi-infaunal suspension feeders.

Species richness and Shannon-Weaver diversities in the deep water changed from February to November. The most unstable season was August while the most stable month was November. Conides et al. (1999) found a similar pattern where winter was the keydivisor season or the key-divisor season is late spring, which were directly attributed to the special environmental conditions in the south of Nisyros Island.

Some species were commonly observed between depths $50 \mathrm{~m}$ and $100 \mathrm{~m}$ and were the main contributors for increasing the richness, but some of their abundances were not so high that the diversity decreased. Gremare et al. (1998) found A. chiajei species at 40 and $44 \mathrm{~m}$ stations within the soft bottoms of the Bay of Banyuls-sur-mer. Apseudes latreillei abundantly found at $50 \mathrm{~m}$ and it decreased to evenness. Tselepides et al. (2000) and Smith 
et al. (2000) found Levinsenia gracilis as one of the most abundant species between 100 and $200 \mathrm{~m}$ over the continental margin of Crete. According to the Makra and Nicolaidou (2000) abundance of this Polychaeta species indicates the moderately disturbed areas of the inner Argolikos Bay. The highest abundance was accounted for a spinculid species Onchnesoma steenstrupi at $100 \mathrm{~m}$ as Tselepides et al. (2000) stated $O$. steenstrup $i$ was one of the most abundant species between 70 and $100 \mathrm{~m}$ (Murina et al. 1999).

Correlation of the benthic community indices with the sediment characteristics showed that the species variety, abundance and community are inversely proportional to mud percentage sorting of sediments. The multivariate statistics also clearly indicated that sediment type is the controlling factor for the differentiation of the segregated benthic assemblages. The organic content complements the sediment type to reinforce this differentiation. This was true in the eastern Mediterranean deep sea (Kroncke et al. 2003). Depth seems to be the governing factor for differentiating the fauna within the stations of similar sediment type in the Aegean Sea (Simboura et al. 1998). Depth and substrate were important factors influencing the structure of macroepibenthic echinoderm assemblages in the English Channel; deeper waters may also provide a more constant hydrodynamic environment, whereas temperature and salinity fluctuations will be greater in shallower waters (Ellis and Rogers 2000). Many physicochemical environmental factors were linked with depth as well as to the distance from the shore and the proximity of terrestrial inputs. In the shallow zone, C. persicus and D. pugilator contributed most to the total similarity. In the deeper zone, those were $A$. laterna and $D$. pugilator. The presence of $C$. persicus mainly discriminated between the zones. Serrano et al. (2006) showed a pattern of two gradients on epibenthic communities of the Cantabrian shelf, Spain: depth/water temperature and sediment characteristics; $D$. pugilator typified the poor sands of inner shelf; fishes (A. laterna, Callyonimus maculatuts) and Anapagusus laevis characterized the assemblage of inner and middle shelf sediments with higher organic content. Organic carbon may be used as an indicator of food energy that is readily available to a variety of benthic organisms but since it contains an unknown retractile proportion it does not display as strong a correlation (Tselepides et al. 2000). In some cases besides the effects of water depth on macrobenthic community structure, other physical and chemical factors (such as flow velocities and organic matter supply) can be important structuring factors as well (Flach and Thomsen 1998). Both unconstrained (nmMDS) and constrained (CAP analysis) ordination methods highlighted a separation of the three depth zones. However, the CAP showed that there was no significant difference in the epifauna assemblages between years of 2000 and 2001 at both depth contours of 5 and $10 \mathrm{~m}$ (Table 4). This could suggest that monthly dredging could not affect the fauna.

In the present study, a total number of alien species including Lessepsian species was found to be 22: 8 fish, 4 molluscan, 7 crustacean and 3 polychaeta species (Table 2). The number of invertebrate Lessepsian species in Turkish seas is as follows: polychaetes (10), decapods (23), amphipods (2), molluscs (48) (Cinar and Ergen 2005, Ergen et al. 2002, Kocatas et al. 2002 a, b). The compilation of data on alien species reported from the Turkish coasts yielded a total of 263 species belonging to 11 systematic groups, of which Mollusca had the highest number of species (85 species), followed by Crustacea (51), fishes (43) and phytobenthos (39) with the Levantine Sea represented by 202 species (Cinar et al. 2005). A total of 963 alien species have been reported from the Mediterranean until December 2005, 218 of which have been classified as excluded (23\%) leaving 745 of the recorded species as valid aliens (Zenetos et al. 2005).

\section{ACKNOWLEDGMENTS}

The present study was carried out within framework of projects (YDABCAG-100Y015) funded by the Scientific and Technical Research 
Council of Turkey (TUBITAK) and a part of MSc Thesis by Mehmet B. Ergev (2002, IMSMETU, Turkey) as well. We thank also Andrew C. Seitz and Argyro Zenetos for their valuable comments and correction of English grammar.

\section{RESUMEN}

Se estudió la distribución espacio-temporal de la epifauna recolectada con un trineo en la plataforma de Armenia Menor, Mar Mediterráneo. Hubo dos comunidades diferentes: una comunidad de aguas someras entre los 5 y 10 metros de profundidad con fondo arenoso habitado en forma abundante por Conomurex persicus, Arnoglossus laterna y Murex trunculus. Conomurex persicus, una especie tropical introducida, predominó en la zona de aguas someras, y la diferenció de la zona profunda. La comunidad profunda (25-150 m) no presentaba especies de aguas someras y estaba dominada por Arnoglossus laterna, Goneplax rhomboides y Parapenaeus longirostris. La estacionalidad no fue un factor importante en la estructura de la comunidad epibentónica presente en toda la plataforma, pero sí lo fue en las aguas someras. La profundidad del fondo del mar fue el factor principal en la estructura de la comunidad en la plataforma. El tamaño del sedimento y el contenido de materia orgánica es también un factor que controla la distribución de la fauna epibentónica.

Palabras clave: epifauna, distribución, plataforma de Armenia menor, mar Mediterráneo oriental.

\section{REFERENCES}

Anderson, M.J. \& J. Robinson. 2003. Generalized discriminant analysis based on distances. Aust. NZ. J. Stat. 45: 301-318.

Anderson, M.J. \& T.J. Willis. 2003. Canonical analysis of principal coordinates: a useful method of constrained ordination for ecology. Ecology 84: 511-525.

Anonymous. 1991. Lecture notes prepared for the training workshop on the statistical treatment and interpretation of marine community data. FIR/MEDPOL/ ALE/2, FAO/IOC/UNEP Training Workshop, FAO, Athens, Greece.

Ates, A.S., T. Katagan, A. Kocatas \& F.E. Yurdabak. 2005. Decapod (Crustacea) fauna of Saros Bay (Northeastern Aegean Sea). Tr. J. Zool. 29: 119-124.

Bakir, K, M. Sezgin \& T. Katagan. 2006. Contribution to the knowledge of alien amphipods off the Turkish coast: Gammaropsis togoensis (Schellenberg, 1925). Aquatic Invasions. 2: 80-82.
Bellan-Santini, D. 1985. The Mediterranean benthos: reflections and problems raised by a classification of the benthic assemblages. In M. MoraitouApostolopoulou \& V. Kiortis, (eds). Mediterranean Marine Ecosystems. Plenum, New York, USA.

Box, G.E.P. \& G. Jenkins. 1976. Time Series Analysis: Forecasting and Control. Holden-Day. San Francisco, California, USA.

Bray, J.R. \& J.T. Curtis. 1957. An ordination of the upland forest communities of southern Wisconsin. Ecol. Monogr. 27: 320-249.

Callaway, R., J. Alsvag, I. Boois, J. Cotter, A. Ford, H. Hinz, S. Jennings, I. Kroncke, J. Lancaster, G. Piet, P. Prince \& S. Ehrich. 2002. Diversity and community structure of epibenthic invertebrates and fish in the North Sea. ICES J. Mar. Sci. 59: 1199-1214.

Cardel, M.J., R. Sarda \& J. Romero. 1999. Spatial changes in sublittoral soft-bottom Polychaeta assemblages due to river inputs and sewage discharges. Acta Oecol. 20: 343-351.

Chicharo, L., A.Chicharo, M. Gaspar, F. Alves \& J. Regala. 2002. Ecological characterization of dredged and non-dredged bivalve fishing areas off south Portugal. J. Mar. Biol. Assoc. UK 82: 41-50.

Cinar, M.E. \& C. Altun. 2007. A preliminary study on population characteristics of the Lessepsian species, Pseudonereis anomala (Polychaeta: Nereididae), in Iskenderun Bay (Levantine Sea, eastern Mediterranean). Tr. J. Zool. 31: 403-41.

Cinar, M.E. \& Z. Ergen. 2005. Lessepsian migrants expanding their distributional ranges; Pseudonereis anomala (Polychaeta: Nereididae) in Izmir Bay (Aegean Sea). J. Mar. Biol. Assoc. UK 85: 313-321.

Cinar, M.E., M. Bilecenoglu, B. Ozturk, T.Katagan \& V. Aysel. 2005. Alien species on the coasts of Turkey. Medit. Mar. Sci. 6: 119-146.

Clarke, K.R. \& R.H. Green. 1988. Statistical design and analysis for a 'biological effects' study. Mar. Ecol. Prog. Ser. 46: 213-226.

Clarke, K.R. \& R.M. Warwick. 1993. Similarity-based testing for community pattern: the 2-way layout with no replication. Mar. Biol. 118:167-176.

Clarke, K.R. \& R.M. Warwick. 2001. Change in marine communities: an approach to statistical analysis and interpretation, 2nd edn. PRIMER-E, Plymouth, Devon United Kingdom.

Conides, A., C. Bogdanos \& A. Diapoulis. 1999. Seasonal ecological variations of phyto- and zoobenthic 
communities in the south of Nisyros Island, Greece. The Environmentalist 19: 109-127.

Cosentino, A. \& S. Giacobbe. 2006. A case study of mollusc and polychaete soft-bottom assemblages submitted to sedimentary instability in the Mediterranean Sea. Mar. Ecol. 27: 170-183.

Ediger, V., G. Evang \& M. Ergin. 1997: Recent surfacial shelf sediments of the Cilician Basin (Turkey), northeastern Mediterranean. Cont. Shelf Res. 17: 1659-1677.

Eleftheriou, A. \& M.R. Robertson. 1992. The effects of experimental scallop dredging on the fauna and physical environment of a shallow sandy community. Neth. J. Sea Res. 30: 289-299.

Ellis, J.R. \& S.I. Rogers. 2000. The distribution, relative abundance and diversity of echinoderms in the eastern English Channel, Bristol Channel, and Irish Sea. J. Mar. Biol. Assoc. UK 80: 127-138.

Ergen, Z. \& M.E. Cinar. 1997. Polychaeta of Antalya Bay (Mediterranean coast of Turkey). Israel J. Zool. 43: 229-241.

Ergen, Z., M.E. Cinar, E. Dagli \& G. Kurt. 2002. Lessepsian polycaete species from the Turkish coasts, p. 50-55. In B. Ozturk \& Basusta N. (eds). Workshop on Lessepsian Migration proceedings, Gokceada. Turkish Marine Research Foundation, Istanbul, Turkey.

Ergin M, 1996. Subaerially exposed Late-Quaternary basinal shelf of the inner Mersin Bay, Eastern Mediterranean: Paleoenvironmental evidence. GeoMar. Lett. 16: 95-100.

Fanelli, E., A.F. Colloca \& G. Ardizzone. 2007: Decapod crustacean assemblages off the West coast of central Italy (western Mediterranean). Sci. Mar. 71: 19-28.

Farina, A.C., J. Freire \& E. Gonzalez-Gurriaran. 1997a. Megabenthic decapod crustacean assemblages on the Galician continental shelf and upper slope (northwest Spain). Mar. Biol. 127: 419-434.

Farina, A.C., J. Freire \& E. Gonzalez-Gurriaran. 1997b. Demersal fish assemblages in the Galician continental shelf and upper slope (NW Spain): spatial structure and long-term changes. Estuar. Coast. Shelf S. 44: 435-454.

Field, J.G., K.R. Clarke \& R.M. Warwick. 1982. A practical strategy for analysing multispecies distribution patterns. Mar. Ecol. Prog. Ser. 8:37-52.

Flach, E. \& L. Thomsen. 1998. Do physical and chemical factors structure the macrobenthic community at a continental slope in the NE Atlantic? Hydrobiologia 376: $265-285$.

Folk, R.L. 1974. Petrology of sediment rocks. Hephill Publishing Company Austin, Texas, USA.

Fredj, G., D.Bellan-Santini \& M. Meinardi. 1992. Etat des connaissances sur la faune marine Mediterranéenne. Bulletin Institut Oceangraphique, Monaco, 9: 133145 .

Galil, B. \& A. Zenetos. 2002. A sea change - exotics in the eastern Mediterranean, p. 325-336. In E. Leppäkoski, Olenin S., Gollasch S. (eds.): Invasive Aquatic Species of Europe: Distributions, impacts and management. Kluwer Academic Publishers Dordrecht, The Netherlands.

Galil, B.S. 2004. Carupa tenuipes Dana, 1851: An indopacific swimming crab new to the Mediterranean (Decapoda, Brachyura, Portunidae). Crustaceana 77: 249-251.

Galil, B.S. 2005. Dorippe quadridens (Decapoda, Dorippidae) - First record of an alien dorippid in the Mediterranean Sea. Crustaceana 78: 497-498.

Gaudette, H.E., W.R. Flight, L. Toner \& D.W. Folger. 1974. An inexpensive titration method for determination of organic carbon in recent sediments. J. Sediment. Petrol. 44: 249-253.

Gray, J.S. 1981. The ecology of marine sediments. Cambridge studies in modern biology 2. Cambridge University, Cambridge, United Kingdom.

Gremare, A., G. Amouroux \& G. Vetion. 1998. Long Term comparison of macrobenthos within the soft bottoms of the Bay of Banyuls-sur-mer (northwestern Mediterranean Sea). J. Sea Res. 40: 281-302.

Gusso, C.C., M.F. Gravina \& F.R. Maggiore. 2001. Temporal variations in soft bottom benthic communities in central Tyrrhenian Sea (Italy). Archo Oceanogr. Limnol. 22: 175-182.

Hinz, H., I. Kroncke \& S. Ehrich. 2004. Seasonal and annual variability in an epifaunal community in the German Bight. Mar. Biol. 144: 735-745.

Holme, N.A. \& A.D. McIntyre. 1971. Methods for the study of Marine Benthos. Blackwell Scientific Publications, Oxford and Edinburgh, London, UK: 137 pp.

Horton, T. A. Diamant \& B.S. Galil. 2004. Ceratothoa steindachneri (Isopoda, Cymothoidae): An unusual record from the Mediterranean. Crustaceana 77: 1145-1148. 
Janssen, R. 1989. Benthic molluscs from the deepwater of the Eastern Mediterranaean Sea, collected during 'Meteor' cruise 5 (1987). Senckenb. Marit. 20: 265-276.

Jennings, S., J. Lancaster, A. Woolmer \& J. Cotter. 1999. Distribution, diversity and abundance of epibenthic fauna in the North Sea. J. Mar. Biol. Assoc. UK 79: 385-399.

Jones, D. L. 2002. Users manual for FATHOM: a Matlab toolbox for multivariate ecological and oceanographic data analysis. Cooperative Institute for Marine and Atmospheric Science, University of Miami-RSMAS, Florida, USA.

Kallianiotis, A., K. Sophronidis, P. Vidoris \& A. Tselepides. 2000. Demersal fish and megafaunal assemblages on the Cretan continental shelf and slope (NE Mediterranean): seasonal variation in species density, biomass and diversity. Prog. Oceanogr. 46: 429-455.

Kamenos, N.A., P.G. Moore \& J.M. Hall-Spencer. 2003. Substratum heterogeneity of dredged vs un-dredged maerl grounds. J. Mar. Biol. Assoc. UK 83: 411-413.

Karakassis, I. \& A. Eleftheriou. 1997. The continental shelf of Crete: structure of macrobenthic communities. Mar. Ecol. Prog. Ser. 160:185-196.

Karakassis, I. \& A. Eleftheriou. 1998. The continental shelf of Crete: The benthic environment. Mar. Ecol.-P S Z N I. 19: 263-277.

Kirim, F., A. Kocatas, T. Katagan, M. Sezgin \& A.S. Ates 2005. Crustacean biodiversity of Padina pavonia (L.) facies along the Aegean Coasts of Turkey. Tr. J. Zool. 29: $159-166$

Kocatas, A., T. Katagan \& A.S. Ates. 2002a. Lessepsian invasion decapod crustaceans at Turkish seas, p. 56-58. In B. Ozturk \& Basusta N. (eds): Workshop on Lessepsian Migration proceedings. Gokceada. Turkish Marine Research Foundation, Istanbul, Turkey.

Kocatas, A., T. Katagan \& M. Sezgin. 2002b. Lessepsian invasion amphipods of the Mediterranean, p. 59-61. In B. Ozturk \& Basusta N. (eds): Workshop on Lessepsian Migration proceedings. Gokceada. Turkish Marine Research Foundation, Istanbul, Turkey.

Kocatas, A., T. Katagan, M. Sezgin, F. Kirim \& C. Kocak. 2004. Crustacean Diversity Among the Cystoseira Facies of the Aegean Coast of Turkey. Tr. J. Zool. 28: 309-316.

Koukouras, A., E. Voultsiadou, M.S. Kitsos \& S. Doulgeraki. 2001. Macrobenthic fauna diversity in the Aegean Sea. Affinities with other Mediterranean regions and the Black Sea. Bios (Macedonia, Greece) 6: 61-76.

Kourelea, E., V. Dimitrios, C. Chariton-Charles, T. Georgios \& C. Louis. 2004. Temporal variations in fine sand assemblages in the North Aegean Sea (Eastern Mediterranean). Int. Rev. Hydrobiol. 89: 175-187.

Kroncke, I., M. Turkay \& D. Fiege. 2003. Macrofauna Communities in the Eastern Mediterranean Deep Sea. Mar. Ecol.-P S Z N I. 24: 193-216.

Makra, A. \& A. Nicolaidou. 2000. Benthic communities of the inner Argolikos Bay. Belg. J. Zool. 130: 61-67.

Margalef R (1985) Environmental control of the mesoscale distribution of primary producers and its bearing to primary production in the Western Mediterranean. In: Moraltou-Apostolopoulou M, Kiortsis V (eds) Mediterranean marine ecosystems. Plenum, New York, USA.

Morello, E.B., C. Froglia, R. James, A. Atkinson \& P.G.Moore. 2006. Medium-term impacts of hydraulic clam dredgers on a macrobenthic community of the Adriatic Sea (Italy). Mar. Biol. 149: 401-413.

Muller, G. 1967. Methods in sedimentary petrology. E. Schweizbart'sche Verlags buch, Stuttgart, Germany.

Murina, G.V.V., M.A. Pancucci-Papadopoulou \& A. Zenetos. 1999. The phylum Sipuncula in the eastern Mediterranean: composition, ecology, zoogeography. J. Mar. Biol. Assoc. UK 79: 821-830.

Mutlu, E. \& M.B. Ergev. 2006. Dynamics and ecology of an Indo-Pacific gastropod, Conomurex persicus in southeastern Turkey. Rev. Biol. Trop. 54: 117-129.

Mutlu, E. 2004. Sexual dimorphisms in radula of Conomurex persicus (Gastropoda: Strombidae) in the Mediterranean Sea. Mar. Biol. 145: 693-698.

NCMR. 2001. Study of the short- and mid-term impact of oil pollution in South Evvoikos Gulf. NCMR Technical Report, Athens, Greece.

Nicolay, K. \& E.R. Manoja. 1983. Strombus (Conomurex) decorus raybaudii $\mathrm{n}$. spp. La Conchiglia The Shell 176-177: 17-18.

Ozcan, T., B.S. Galil, K. Bakir \& T. Katagan. 2006: The first record of the banana prawn Fenneropenaeus merguiensis (De Man, 1888) (Crustacea: Decapoda: Penaeidae) from the Mediterranean Sea. Aquatic Invasions 1: 286-288. 
Peres, J.M. 1967. The Mediterranean benthos. Oceanogr Mar Biol Annu Rev 5: 449-533

Peres, J.M. 1982a. Zonation. General features of organismic assemblages in pelagial and benthal. Structure and dynamics of assemblages. Major benthic assemblages. Specific benthic assemblages. In Kinne O (ed) Marine ecology, John Wiley, Chichester V-1: 9-66, 119-186,373-581.

Peres, J.M. 1982b. Major benthic assemblages. Mar. Ecol. 5: $372-522$

Pielou, E.C. 1966. Species diversity and pattern diversity in the study of ecological succession. J. Theor. Biol. 10: $370-383$.

Sarda, R., S. Pinedo \& D. Martin. 1999. Seasonal dynamics of macroinfaunal key species inhabiting shallow softbottoms in the bay of Blanes (NW Mediterranean). Acta Oecol. 20: 315-326.

Sarda, R., S. Pinedo, A. Gremare \& S. Taboada. 2000. Changes in the dynamics of shallow sandy-bottom assemblages due to sand extraction in the Catalan Western Mediterranean Sea. ICES J. Mar. Sci. 57: 1446-1453.

Serrano, A., F. Sanchez \& G. Garcia-Castrillo. 2006. Epibenthic communities of trawlable grounds of the Cantabrian Sea. Sci. Mar. 70: 149-159.

Shannon, C.E. \& W. Weaver. 1968. The mathematical theory of communication. Urbana University Press. Illinois, USA.

Simboura, N., A. Zenetos, M.A. Pancucci-Papadopoulou, M. Thessalaou-Legaki \& S. Papaspyrou. 1998. A baseline study on benthic species distribution in two neighboring gulfs, with and without access to bottom trawling. Mar. Ecol. P.S.Z.N.I. 19: 293-309.

Simboura, N., Nicolaidou, A., Thessalou-Legaki, M., 2000. Polychaeta communities of Greece: An ecological overview. Mar. Ecol. 21: 129-144.

Smith, C.J., K.N. Papadopoulou \& S. Diliberto. 2000. Impact of otter trawling on an eastern Mediterranean commercial trawl fishing ground. ICES J. Mar. Sci. 57: $1340-1351$.
Sokal R.R., Rohlf F.J. (eds).1973. Introduction to biostatistics. W.F. Freeman and Company, San Francisco.

Taylor, L.R. 1961. Aggregation, variance and the mean. Nature 189: 732-753.

Tselepides, A., K.N. Papadopoulou, D. Podaras, W. Plaiti \& D. Kousoubas. 2000. Macrobenthic community structure over the continental margin of Crete (South Aegean Sea, NE Mediterranean). Prog. Oceonagr. 46: 401-428.

Tsutsumi, H., S. Fukunaga, N. Fujita \& M. Sumida. 1990. Relationship between growth of Capitella sp. and organic enrichment of the sediment. Mar. Ecol-Prog. Ser. 63: 157-162.

UNEP/MAP. 2004. Guidelines for the development of ecological status and stress reduction indicators for the Mediterranean region. MAP Technical Reports Series 154, Athens, Greece.

Vamvakas, C. 1970. Peuplements benthiques des substrats meubles du sud de la Mer Ege'e. Tethys 2: 89-129.

Yokes, B. \& B.S. Galil. 2006. New records of alien decapods (Crustacea) from the Mediterranean coast of Turkey, with a description of a new palaemonid species. Zoosystema 28: 747-755.

Yokes, M.B., S.U. Karhan, E. Okus, A. Yuksek, A.A. Yilmaz, I.N. Yilmaz, N. Demirel, V. Demir \& B.S. Galil. 2007. Alien Crustacean Decapods from the Aegean Coast of Turkey. Aquatic Invasions 2: 162168.

Zenetos, A., I. Siokou-Frangou, O. Gotsis-Skretas \& S. Groom. 2002. The Mediterranean Sea - blue oxygenrich, nutrient-poor waters. In: Europe's biodiversity - biogeographical regions and seas, Seas around Europe. (Downloaded: 27 April, 2006, http://reports. eea.eu.int/report_2002_0524_154909/en).

Zenetos, A., M.E. Cinar, M.A. Pancuci-Papadopoulou, J.G. Harmelin, G. Furnari, F. Andaloro, N. Belou, N. Streftaris \& H. Zibrowius. 2005. Annotated list of marine alien species in the Mediterranean with records of the worst invasive species. Medit. Mar. Sci. 6: 63-118. 